\title{
Landráðakenning Pórs Whitehead: Nokkrar athugasemdir við ritið Sovét-Ísland óskalandið
}

\author{
Jón Ólafsson
}

\begin{abstract}
Ágrip: Í greininni er fjallað um helstu niðurstöður bókar Pórs Whitehead, Sovét-Î́sland óskalandið: Aðdragandi byltingar sem aldrei varð. Rök eru færð fyrir pví að Pór takist ekki með neinum sannfærandi hætti að sýna fram á réttmæti fullyrðinga sinna. Í framhaldi af pví er fjallað um heimildir um Moskvutengsl íslenskra kommúnista og pví haldið fram að í nokkrum veigamiklum atriðum gefi eðlilegur lestur heimildanna tilefni til niðurstaðna sem eru gagnstæðar niðurstöðum Pórs. Pór heldur pví fram að íslenskir kommúnistar hafi á tímabili verið ógnun við íslenskt ríkisvald, en í greininni eru rök færð fyrir pví að svo hafi ekki verið.
\end{abstract}

Lykilorð: Kommúnistaflokkur Îslands; Alpjóðasamband kommúnista; verkalýðsátök; Sovétríkin; ofbeldi

\begin{abstract}
The paper discusses some of the central theses in Pór Whitehead's book Sovét-Ísland óskalandið: Aðdragandi byltingar sem aldrei varð, whose title can be loosely translated as Dreams of a Soviet Iceland: Preparations for a revolution that never came. I argue here that Pór Whitehead fails to demonstrate the validity of the claims in his book because his use of primary sources is limited and biased. The paper goes on to discuss the available sources on Icelandic communists' connections and contacts in Moscow, and points out that in many cases a close reading of these sources seems to lead to conclusions which contradict the book's claims. Pór Whitehead's position is that Icelandic communists for a time posed a real threat to the Icelandic state, but this paper argues that such was never the case.
\end{abstract}

Keywords: Communist Party of Iceland; Communist International; labour conflict; Soviet Union; violence

\section{Inngangur}

Меð hverju árinu sem líður eykst vitneskja okkar um martraðarsamfélag stalínismans. Fram að hruni Sovétríkjanna var heimildum um ógnarstjórnina haldið leyndum. Öllum rannsóknum á sögu og samfélagi Sovétríkjanna var stýrt. Innanlands purftu rannsakendur að beygja sig undir pær hugmyndir sem stjórnvöld vildu hafa um próun samfélagsins eftir byltingu. Á Vesturlöndum ríkti pað viðhorf að til pess að geta fjallað af viti um Sovétríkin yrðu menn einnig að taka skýra afstöðu gegn sovéskum stjórnarháttum. Pannig tengdist fræðileg umfjöllun um Sovétríkin óhjákvæmilega pólitískri tvískiptingu heimsins.

Nú eru meira en tuttugu ár liðin síðan Sovétríkin liðu undir lok. Á peim tíma hefur margt breyst. Aðgangur að skjalasöfnum er tiltölulega greiður, ráðgátur hafa verið upplýstar og leyndarmál afhjúpuð. Smátt og smátt hefur tekist að draga upp myndir af gangvirki stalínismans, sem rista dýpra en hin margtuggna lýsing á grimma einræðisherranum. Á tíunda ára- 
tugnum, pegar margir peirra sem höfðu sætt ofsóknum á Sovéttímanum voru enn á lífi, komu út viðtöl og æviminningar sem vörpuðu ljósi á líf fólks undir Stalín. Örlagasögur einstaklinga og fjölskyldna hafa komist í sviðsljósið, dagbækur, bréf og önnur persónuleg gögn frá Stalíntímanum hafa verið gefin út og um pau verið fjallað. Möguleikar okkar til að skilja og öðlast pekkingu á samfélagi stalínismans hafa aldrei verið meiri en nú.

pegar upplýsingar urðu aðgengilegar um leyndarmál Sovétstjórnarinnar frá og með árinu 1992, beindist áhugi fjölmiðla á Vesturlöndum sérstaklega að einu atriði. Рað voru tengsl einstaklinga og flokka í vestrænum ríkjum við Kommúnistaflokk Sovétríkjanna, og við Komintern, alpjóðasamband kommúnista sem starfaði á árunum 1919 til 1943. Ísland fór ekki varhluta af pessu. Hér á landi hafði starfað kommúnistahreyfing frá árinu 1920 og kommúnistaflokkur verið stofnaður formlega árið 1930. Pótt hann væri lagður niður strax 1938 í págu víðtækara samstarfs á vinstri væng stjórnmálanna, héldu forystumenn arftakans, Sósíalistaflokksins, áfram að eiga í trúnaðarsambandi við sovéska kommúnistaflokkinn allt til loka áttunda áratugarins. ${ }^{1}$

pessi tengsl voru að sjálfsögðu viðkvæmt mál, ekki síst pegar í ljós kom að Sósíalistaflokknum hafði verið úthlutað talsverðum fjárhæðum úr sérstökum sjóði sem Kommúnistaflokkur Sovétríkjanna stóð að á sjötta og sjöunda áratugnum. ${ }^{2}$ Pótt ekkert hafi nákvæmlega komið á daginn um hvernig pessu fé var ráđstafað, má gera ráð fyrir að Sovétsamböndin hafi verið lykilpáttur í pví að íslenskum sósíalistum tókst að fjármagna öfluga starfsemi sína í útgáfu- og menningarmálum á pessum tíma. Allt hefur petta legið fyrir í grófum dráttum lengi og valdið talsverðum umræðum um fortíðarvanda íslenskrar vinstrihreyfingar og hugsanlegt uppgjör við hann. Hörðustu andstæðingar vinstrimanna hafa krafist pess að peir játuðu og iðruðust og viljað sjá almenna og opinbera fordæmingu á vináttu peirra við Sovétforystuna. ${ }^{3}$

pór Whitehead, prófessor í sagnfræði við Háskóla Íslands, stígur hinsvegar skrefi lengra en jafnvel hörðustu andstæðingar kommúnisma hafa gert áður. İ riti sínu Sovét-Ísland óskalandið: Aðdragandi byltingar sem aldrei varð gerir hann ítarlega grein fyrir peirri kenningu sinni að íslenskir kommúnistar hafi ekki verið annað en pjónar Moskvuvaldsins. Pannig hafi sovétvinátta peirra ekki aðeins verið vafasöm afstaða til harðstjórnar kommúnista, heldur fullkomin hollusta við erlent vald ásamt loforði um að styðja pað til áhrifa og jafnvel yfirráða á Íslandi, væri pess krafist. Pór heldur pví fram að átök í íslensku samfélagi á kreppuárunum „sem hingað til hafa verið skýrð sem óhjákvæmilegar afleiðingar af kreppunni miklu“ hafi í raun verið hluti byltingarundirbúnings Kominterns á Íslandi sem sambandið skipaði pjónum sínum að vinna að (bls. 425). Hann telur að alpjóðasambandið hafi búið flokkinn til, stýrt honum og gefið fyrirmæli um stefnu, yfirlýsingar og aðgerðir sem félagar í honum hlýddu í einu og öllu (bls. 74). ${ }^{4}$

1 Sjá Jón Ólafsson, „Staðreyndir eða heilaspuni,“ ”bls. 44-45.

2 Jón Ólafsson, Karu félagar: Íslenskir sósíalistar og Sovétríkin 1920-1960, bls. 195.

3 Morgunblaðið, ritstjórnargrein, 29.7 1992, bls. 22.

4 Pór hefur reifað kenningu sína í fyrri skrifum, einkum í grein sinni „Smáríki og heimsbylting“ sem birtist í tímaritinu Pjóðmál fyrir sex árum. Ég hef bent á helstu vandkvæðin við niðurstöður hans í greinum í Lesbók Morgunblaðsins. Yfirlit yfir greinar mínar og svör hans úr Lesbók Morgunblaðsins er að finna í heimildaskrá aftast í pessari grein. 
Pór telur að Ísland hafi verið álitið gríðarlega mikilvægt hernaðarlega af Sovétstjórninni frá upphafi. Lenín hafi nefnilega af framsýni sinni séð kalda stríðið fyrir strax árið 1920 (bls. 104-105). Pá telur hann að öryggisráðstafanir íslenskra stjórnvalda hafi verið svo vanmáttugar að vel pjálfaður og vopnum búinn hópur hefði vel getað tekið völdin, jafnvel pótt hann væri ekki fjölmennur (bls. 95-102). Íslenskir kommúnistar hafi ennfremur fengið fyrirmæli frá Komintern um að safna vopnum og hafi strax á fjórða áratugnum átt yfir dágóðu vopnabúri að ráða (bls. 148-152). Pór beinir sjónum fyrst og fremst að fjórða og fimmta áratug síðustu aldar, en dregur bó ekki dul á pá skoðun sína að kommúnistar á Íslandi hafi starfað eftir fyrirmælum frá Moskvu áfram og hættan á ofbeldisverkum peirra og jafnvel valdatöku verið viðvarandi jafnvel fram á sjötta áratuginn ef ekki enn lengur (bls. 429-430). Pótt hér sé langt gengið er ljóst af viðtökum bókar hans að sumir telja kenninguna sannfærandi. Áköfustu aðdáendur Pórs hafa lofað hana sem vatnaskil í íslenskri sagnfræði og jafnvel krafist endurskoðunar námsefnis í Íslandssögu með hliðsjón af henni. Pað er ekki síst vegna pessara viðtakna bókarinnar sem nauðsynlegt er að fjalla um kenninguna og leggja mat á hana. ${ }^{5}$

Niðurstaða mín, sem ég mun gera grein fyrir og skýra hér á eftir, er sú að kenning Pórs standist enga skoðun. Vandinn við kenninguna er tvípættur. Í fyrsta lagi fjallar hún um atburði sem urðu aldrei. Рað er vissum annmörkum háð að gera mikið úr hættu á valdatöku kommúnista pegar staðreyndin er sú að peir reyndu aldrei að taka völdin, beittu aldrei vopnum eða aðferðum hernaðar og lögðu sérstaka áherslu á andstöðu við ofbeldi í málflutningi sínum lengst af. Í öðru lagi skortir Pór heimildir. Hann byggir ályktanir sínar á litlum hluta tiltækra heimilda um sovéttengsl íslenskra kommúnista auk pess sem ályktanir hans eru iðulega á skjön við pað sem heimildirnar virðast segja. Pór vinnur enga sjálfstæða heimildavinnu um Moskvutengslin til að styðja fullyrðingar sínar. Hann lætur nægja að byggja á heimildavinnu annarra höfunda um efnið, einkum undirritaðs, sem hann sakar pó einnig stöðugt um að leyna heimildum (sjá t.d. bls. 156, nmgr.).

раð er undrunarefni að pór Whitehead skuli ráðast í jafn viðamikið verk og SovétÍsland er og setja fram jafn róttækar kenningar um áratuga samsæri hóps Îslendinga, án pess að afla sér tiltækra heimilda. Helstu heimildir hans eru skjöl úr safni Kominterns sem sá er petta skrifar notaði við gerð sjónvarpspátta fyrir allmörgum árum, og afhenti Handritadeild Landsbókasafnsins að pví verki loknu. Einnig hef ég birt fáeinar heimildir mínar úr Kominternsafninu á eigin vefsíðu. Auk heimilda sem frá mér eru komnar virðist Pór hafa kynnt sér heimildir sem Arnór Hannibalsson vísar til í bók sinni Moskvulínan. En allt petta er pó aðeins lítill hluti af pví efni um Ísland sem finna má í skjalasafni Kominterns.

Skeytingarleysi Pórs um sjálfstæða heimildaöflun kann að stafa af misskilningi. Pór fullyrðir á nokkrum stöðum í bókinni að Kominternsafnið sé ekki nema að litlu leyti opið fræðimönnum. Deildir pess séu „hálflokaðar“ og skjöl um íslenska kommúnistaflokkinn séu enn leynileg (bls. 255). Allt er petta rangt. Á peim tæpu tuttugu árum sem liðin eru frá pví að fræðimenn fengu aðgang að safninu hefur pað að mestu leyti verið opnað. Hluti Kominternskjalanna hefur um nokkurra ára skeið einnig verið aðgengilegur í rafrænu gagnasafni sem hægt er að gerast áskrifandi að gegn gjaldi. Par er skjalaskrá safnsins par að auki í gjald-

5 Sjá t.d. Styrmir Gunnarsson, „Sovét-Ísland óskalandið eftir Pór Whitehead,“bls. 83-85. 
frjálsum aðgangi og pví auðvelt að staðsetja öll helstu gögn safnsins par sem Ísland kemur við sögu. ${ }^{6}$ Pær heimildir sem ekki eru orðnar hluti af pessu rafræna safni eru aðgengilegar á skjalasafni Kominterns í Moskvu sem veitir fræðimönnum endurgjaldslausa pjónustu og sérfræðiaðstoð. Ekki er tungumálið nein veruleg hindrun heldur par sem pýska var aðalsamskiptatungumál Kominterns, en ekki rússneska.

Рað er vissulega rétt að enn hefur ekki verið veittur aðgangur að ákveðnum skjölum safnsins, par á meðal pví efni sem varðar svonefnda Alpjóðasamskiptadeild Kominterns (OMS). Einnig er aðgangur að persónulegum upplýsingum um einstaklinga sem störfuðu fyrir Komintern, eða dvöldust í Sovétríkjunum á vegum sambandsins, takmarkaður. En allt sem varðar aðildarflokka Kominterns, flokkskólana í Moskvu og flestar aðrar stofnanir Kominterns er aðgengilegt rafrænt eða á safninu sjálfu. Sagnfræðingi sem raunverulega hefur hug á að kynna sér Kominterntengsl Íslendinga er pví ekkert að vanbúnaði að gera pað, jafnvel pó að rússneskukunnáttu sé ekki fyrir að fara. ${ }^{7}$

Í pessari grein mun ég fara í saumana á nokkrum lykilatriðum í kenningu Pórs til að draga fram pann átakanlega heimildaskort sem einkennir hana. Pannig sýni ég í fyrsta lagi að engin leið er að tengja skólagöngu íslenskra kommúnista í Moskvu við kerfisbundna hernaðarpjálfun. Í öðru lagi fer pví fjarri að heimildir um samskipti íslenskra kommúnista við Moskvu bendi til að peir hafi verið auðsveipir pjónar Moskvuvaldsins og í priðja lagi að heimildir Pórs sýna ekki að starfsemi kommúnista hafi verið ógnun við íslenskt ríkisvald.

Kommúnistar töluðu digurbarkalega á Íslandi, eins og annarsstaðar í upphafi fjórða áratugarins pegar kreppa geisaði á Vesturlöndum, og Sovétríkin virtust vera á fljúgandi ferð inn í framtíðina. En hættu metur enginn út frá digurbarkalegu tali, enda er haldbesta skýringin á pví að stjórnvöld gripu ekki til kerfisbundinna ráđstafana gegn kommúnistum sú að pau hafi aldrei óttast tilraun til valdaráns. Hættan var frekar sú, einkum pegar leið á, að Ísland yrði of háð Sovétríkjunum efnahagslega vegna peirra góðu viðskiptakjara sem Sovétríkin buðu Îslandi öll kaldastríðsárin. ${ }^{8}$

Раð er rétt að taka fram að markmið mitt með pessari grein er ekki að „afsanna“ fullyrðingar Pórs. Ég læt mér nægja að draga fram pann galla peirra að ónóg (eða engin) rök styðji pær. Pær eru með öðrum orðum ófræðilegar. pað er ekki par með sagt að pólitískir samherjar pórs myndu ekki áfram vilja taka undir með honum. En pað er stór munur á pólitískum ritum og fræðilegum verkum. Staðhæfingar Pórs um eðli vinstrihreyfingarinnar (bls. 63), varnarleysi íslensks ríkisvalds (bls. 430-431), hætturnar sem kommúnisminn hafi búið öryggi Íslands í

6 Upplýsingar um rafrænan gagnagrunn (á ensku og rússnesku) má finna hér: http://comintern-online.com.

7 Petta get ég vitnað um af eigin reynslu, par sem ég hef verið reglulegur gestur safnsins undanfarin tuttugu ár og hef á peim tíma farið yfir stóran hluta peirra gagna pess sem varða Ísland. Рað gefur hinsvegar auga leið að ég hef ekki ljósritað pessi skjöl nema að litlu leyti og get ekki miðlað öðrum áhugamönnum um pessi mál af öllum heimildum safnsins. pað er pví vitaskuld fráleitt að halda að ljósrit sem ég og fleiri hafa flutt hingað til lands úr pessu safni geti dugað sem heimildaforði fræðimanns sem tekur vinnu sína jafn alvarlega og Pór virðist gera. Skjalasafn Kominterns par sem einnig er að finna gögn Rússneska kommúnistaflokksins til 1953 heitir nú Российский государственный архив социально-политической истории, skammstafað РГАСПИ (RGASPI). Upplýsingar um pað má finna (á rússnesku) hér: http://www.rusarchives.ru/federal/rgaspi.

8 Jón Ólafsson, Koeru félagar, bls. 228-232. 
bland við upphafningu hans á stjórnmálaleiðtogum pjóðarinnar (bls. 331, 401, 413-14), einlæga hrifningu á íslenskum lögreglumönnum og dyggðum peirra, sem jafnvel birtist í aðdáunarorðum um einkennisbúninga peirra og útlit $($ bls. 84,177$)$ undirstrika hin pólitísku markmið bókarinnar. ${ }^{9}$

\section{2. Íslendingar læra að stjórna flokki}

Skýring Pórs á róstum kreppuáranna byggir á skilningi hans á samstarfi Kominterns og aðildarflokka pess um menntun starfsmanna kommúnistaflokka á fjórða áratugnum. Pór er sannfærður um að peir Îslendingar sem stunduðu nám á vegum flokksins í Moskvu hafi markvisst verið pjálfaðir í pví að leiða og skipuleggja götubardaga og hernað af ýmsu tagi. Đessi pjálfun hafi gert Kommúnistaflokki Íslands kleift að ná undirtökunum í hinum ýmsu aðgerðum og óeirðum, skipuleggja átök og leiða pau (bls. 130, 166, 151, 158).

Á árunum 1929 til 1938 stunduðu 23 Íslendingar nám í Moskvu, par af 22 í flokkskólum. ${ }^{10}$ Skólarnir voru tveir: Vesturháskólinn svokallaði, sem starfaði frá 1922 til 1936, og Lenínskólinn en hann starfaði frá 1926 til 1938. ${ }^{11}$ Fæstir Îslendinganna upplýstu mikið um reynslu sína síðar og aðeins einn, Benjamín Eiríksson, skrifaði um hana. Gögn annars, Andrésar Straumland, hafa varðveist, par á meðal dagbók frá fyrstu og síðustu vikum dvalar hans. Fáeinir aðrir fyrrverandi nemendur sögðu frá náminu í samtölum. Viðtekin skoðun sagnfræðinga sem skrifað hafa um flokkskólana er að peir hafi fyrst og fremst verið hugmyndafræðilegar pjálfunarbúðir og heimildir um pátttöku Íslendinga staðfesta pessa viðteknu skoðun. ${ }^{12}$

Pór staðhæfir hinsvegar að hernaður hafi ekki aðeins verið hluti af námi í skólunum. Allt námið hafi lotið að neðanjarðarstarfsemi auk pess sem nemendur hafi verið skyldaðir til

9 Eftir að pessari grein var að mestu lokið, birtist grein Skafta Ingimarssonar, „Fimmta herdeildin, “ 1 tímaritinu Sögu. Skafti fjallar um bók Pórs á svipuðum forsendum og gert er í pessari grein og kemst að niðurstöðum sem eru í fullu samræmi við niðurstöður mínar. Par sem sjónarhorn mitt er pó annað en Skafta og gagnrýni mín beinist fyrst og fremst að notkun heimilda frá Moskvu, var niðurstaða mín bó sú að eðlilegt væri að birta pessa grein í óbreyttri mynd.

10 Peir voru: Jens Figved (RGASPI 495219 48), Andrés Straumland (RGASPI 495219 47), Eyjólfur Árnason (RGASPI 495219 39), Jafet Ottósson (RGASPI 495219 60), póroddur Gudmundsson (RGASPI 4952194 , 38), Dýrleif Árnadóttir (RGASPI 495219 3), Haraldur Bjarnason (RGASPI 495219 67), Eggert Porbjarnason (RGASPI 495219 12), Gísli Indriðason (RGASPI 495219 44), Hallgrímur Hallgrímsson (RGASPI 495219 33), Helgi Guðlaugsson (RGASPI 495219 59), Kristján Júlíusson (RGASPI 495219 41), Lilja Halblaub (RGASPI 495219 42), Stefán Pjetursson (RGASPI 495219 36), Steingrímur Aðalsteinsson (RGASPI 495219 5), Jóhannes Jósepsson (RGASPI 495219 50), Skafti Einarsson (RGASPI 495219 37), Eymundur Magnússon (RGASPI 495219 40), Guðrún Rafnsdóttir (RGASPI 495219 43), Hjalti Árnason (RGASPI 495219 53), Elísabet Eiríksdóttir (RGASPI 495219 54), Benjamín Eiríksson (RGASPI 495219 49), Ásgeir Blöndal Magnússon (RGASPI 495219 24).

11 Коммунистический унвиерситет народных меншинств запада, skammstafað КУНM3 (KUNMZ) og Международная ленинская школа, skammstafað МЛШ (MLSh).

12 Sjá um petta: J.T. Murphy, „Das Erste Jahr der Lenin-Schule und ihre Perspektiven,“ bls. 275; Gidon Cohen, „Stalin's sausage machine: British Students at the International Lenin School," bls. 331; Julia Köstenberger, „Die Internationale Leninschule, “ bls. 297-299; Joni Krekola, „The Finnish sector at the International Lenin School,“ bls. 289-290; Ole-Martin Rønning, Stalins elever, bls. 86-94. 
pátttöku í sérstökum herpjálfunarbúðum eftir að skólanum lauk á sumrin (bls. 95-96). Hann dregur svo pá ályktun að hernaðarnámið hafi verið hagnýtur byltingarundirbúningur auk pess sem pað hafi átt að búa kommúnistaflokka undir stofnun vopnaðra byltingarsveita. Petta hafi öllum kommúnistaflokkum borið skylda til að gera, par á meðal Kommúnistaflokki Îslands (bls. 99). Pessi niðurstaða hans skiptir verulegu máli í bókinni allri, par sem hann vísar jafnan til pessarar meintu herpjálfunar pegar hann fjallar um verkfallsaðgerðir og pólitísk átök og virðist gera ráð fyrir að slík pjálfun og reynsla hafi leikið stórt hlutverk í starfsemi Sósíalistaflokksins eftir að Komintern leið undir lok, en sambandið var lagt niður árið 1943. Hann líkir náminu par m.a.s. við pá pjálfun sem leynipjónustur veita (bls. 103).

Nú er staðreyndin sú að engir Îslendinganna sem stunduðu nám í skólunum hafa sagt frá hernaðarpjálfun par utan pjálfunar í skotfimi og ípróttapjálfunar með hernaðarlegu yfirbragði (bls. 97). Í gögnum Andrésar Straumland kemur fram að herfræði hefur verið hluti af stjórnmálanámi hans veturinn 1930-1931, en par er um bóklegt nám að ræða og aðeins fáeinar stundir í námskeiði vetrarins. Að öðru leyti hafa engar munnlegar eða skriflegar heimildir komið fram um hernaðarpjálfun Íslendinga. Allar fullyrðingar Pórs um slíka pjálfun eru pví getgátur. ${ }^{13}$

Komintern gat vissulega boðið upp á hernaðarpjálfun væri pörf talin á henni. En aðstæður kommúnista heima fyrir voru mismunandi og pví mismikil pörf á pjálfun flokksmanna í hernaðar- eða neðanjarðarstarfi. Kommúnistaflokkar á Íslandi, í Danmörku, Noregi og Svípjóð störfuðu fyrir opnum tjöldum og petta skipti að sjálfsögðu höfuðmáli um framtíðarhlutverk nemendanna. Verkefni peirra var að efla ítök og auka fylgi flokka sinna í umhverfi sem var í meginatriðum friðsamlegt. Finnskir kommúnistar, svo dæmi sé tekið, bjuggu við önnur skilyrði par sem flokkur peirra var ólöglegur og starfaði neðanjarðar. Finnar voru álíka margir í Vesturháskólanum og Lenínskólanum og nemendur frá öðrum Norðurlöndum samanlagt. Finnskir nemendur sem fóru heim eftir nám í Moskvu purftu að fara huldu höfði eða villa á sér heimildir; verkefni peirra var að vinna með ólöglegum flokki að neðanjarðarstarfsemi af ýmsu tagi. Slík verkefni biðu ekki Íslendinga, Svía, Norðmanna og Dana. ${ }^{14}$

Pegar litið er á umsagnir um nemendur sem luku eins, tveggja og priggja ára námsbrautum við Vesturháskólann og Lenínskólann sést vel hverskonar hlutverk gert var ráð fyrir að peir tækju að sér að náminu loknu. Fyrsti Íslendingurinn, Jens Figved, fékk eftirfarandi vitnisburð pegar hann lauk námi sínu 1932:

Brun Jan. ${ }^{15} 25$ ára gamall. Sjómaður, fiskimaður, byggingaverkamaður. 9 ára reynsla af verkamannavinnu. Félagi í kommúníska andstöðuarminum í Íslenska verkamannaflokknum [Albýðuflokknum] frá 1926.

Traustur og áreiðanlegur flokksfélagi. Góður agi. Góður félagi. Pólitískt virkur og áhugasamur.

13 PÍ. Sögusafn verkalýðshreyfingarinnar. B-01: 1/3. Skólagögn Andrésar Straumland. Pað vill raunar svo einkennilega til að Pór nýtir sér ekki pessar heimildir pó að pær hafi verið aðgengilegar lengi og ég fjalli stuttlega um pær í Koru félögum, sjá bls. 65-67.

14 Joni Krekola ræðir petta atriði sérstaklega í grein sinni um finnska kommúnista í Lenínskólanum, sjá bls. 290292. Sjá einnig Julia Köstenberger, „Die Internationale Leninschule,“ bls. 289.

15 Erlendir flokksmenn sem dvöldu í Moskvu á vegum Kominterns fengu oftast dulnefni. Jan Brun var dulefni Jens. 
Mælt er með honum til leiðandi flokksstarfa einkum til verkefna á sviði efnahags- og verkalýðsmála. $^{16}$

Jens var í hópi fjórtán nemenda sem luku priggja ára námsbraut petta vor. Hinir voru flestir norskir og eru umsagnir um pá samskonar. Mælt er með peim til ýmissa starfa innan flokka sinna. Sama vor luku tveir Íslendingar tveggja ára námsbraut við sama skóla. Peir voru í hópi 15 félaga frá Noregi og Danmörku auk Íslands. Eyjólfur Árnason (dulnefni Robert Frank) hlaut pessa umsögn:

Robert Frank. Island.

22 ára gamall. Hafnarverkamaður. Tilheyrði kommúnísku andstöðunni frá 1928 og hefur verið félagi í Kommúnistaflokki Íslands frá stofnun hans árið 1930.

Áreiðanlegur og staðfastur félagi. Félagslega hæfur. Vel proskaður pólitískt en hefur pó ekki sigrast á vissri tilhneigingu til einstaklingshyggju. Hefur ekki proskaða sjálfsgagnrýni.

Mælt er með honum í leiðandi flokksstörf í atvinnufyrirtækjum og sem leiðbeinanda í hverfafélögum. ${ }^{17}$

Félagi hans Póroddur Guðmundsson (dulnefni Otto Stein) frá Siglufirði hafði lent í útistöðum við tvo félaga sína sumarið áður en haft betur, á meðan peir dvöldust sem starfsnemar Kominterns í fiskimannaporpi nyrst á Kolaskaga, eins og sjá má á umsögninni um hann sem er mjög lofsamleg, miðað við umsagnirnar almennt:

Otto Stein. Island.

28 ára gamall. Hafnarverkamaður og sjómaður. Hefur stundað verkamannavinnu í 15 ár. Hefur tilheyrt kommúnísku andstöðunni í íslenska verkamannaflokknum [Alpýðuflokknum] frá 1925, flokksfélagi frá stofnun Kommúnistaflokks Íslands (1930).

Áreiðanlegur og staðfastur félagi. Félagslega hæfur. Er proskaður pólitískt og mjög virkur. Góð sjálfsgagnrýni. Leiðtogaeiginleikar.

Mælt er með honum til leiðandi flokksstarfa í atvinnufyrirtækjum og sem leiðbeinanda mið-

stjórnar í efnahagsbaráttu. ${ }^{18}$

Umsagnirnar bera með sér hverskonar pjálfun námið í Vesturháskólanum fól í sér. Pað miðaði að pví að búa til stétt flokksstarfsmanna til að halda uppi starfsemi flokksins og deilda hans heima fyrir, sinna áróðurs- og fræðslustarfi, laða fólk að flokknum og fylgjast með pví að félagar hefðu réttar skoðanir, skildu atburði eftir „línunni“ og væru færir um að bregðast „rétt“ við atvikum sem upp kynnu að koma í starfinu heima fyrir.

\section{Hernaðarbjálfun í flokkskólunum}

Engar einhlítar upplýsingar hafa komið fram um hvort flokkskólanemendur almennt fengu pjálfun í sprengjugerð, skipulagi götubardaga, aðferðum skæruhernaðar, aðferðum leyniskyttna og pess háttar. Раð blasir hinsvegar við af öllum gögnum um skólana að peir voru fyrst 
og fremst hugmyndafræðilegar pjálfunarbúðir og námsefni miðað við pað. Pjálfun sem tengist hernaði má pví líkja við íprótta- eða vélritunarkennslu í almennum skóla: Hún er ekkert aðalatriði námsins. İ skýrslu yfirmanns Norðurlandadeildar Vesturháskólans sem gerð var 1933 er talað um að nemendurnir hafi hlotið „,visst hernaðarlegt uppeldi“ en par er einungis átt við bardagaípróttir og skotfimi að pví er virðist, hugsanlega einnig reiðmennsku og skíðagöngu. Breskir Vesturháskólanemendur um miðjan priðja áratuginn lærðu að stjórna járnbrautarlest, en sú pjálfun naut lítilla vinsælda og virðist hafa verið aflögð. ${ }^{19}$

Ole Martin Rønning segir í nýlegri doktorsritgerð sinni að hernaðarpjálfun norskra nemenda í Lenínskólanum hafi verið „hreint aukatriði.“ Hinsvegar hafi meiri áhersla verið lögð á að búa nemendur undir ólöglegt starf pannig að peir væru viðbúnir breyttum baráttuaðferðum ef flokkur peirra yrði bannaður. ${ }^{20}$ Slík var einmitt staða Finna og pví ekki að undra að meiri áhersla hafi verið á hernaðarpjálfun og ólöglega starfsemi meðal peirra heldur en Íslendinga.

Heimildir eru um tveggja vikna pjálfunarbúðir fyrir enskumælandi nemendur Lenínskólans sumarið 1936. Pessar tveggja vikna búðir póttu hinsvegar svo tilgangslitlar að fulltrúi bandaríska kommúnistaflokksins hjá Komintern lagði til að pær yrðu ekki endurteknar. Alltof áhættusamt væri að láta Bandaríkjamenn klæðast sovéskum einkennisbúningum og par að auki sé herpjálfunin sjálf ópörf: „Aukinn líkamsprótt, sem er eina raunverulega gagnið af pessari tveggja vikna pjálfun, má auðveldlega fá með venjulegum ípróttabúðum án einkennisbúninga, par sem nemendur læra box, glímu, skotfimi og aðrar ípróttagreinar. “21

Pór heldur pví fram að par sem „vopnuð uppreisn“ er á námskrá Finnsku deildarinnar í Lenínskólanum árið 1931 til 1932 megi draga af pví pá ályktun að Íslendingar hafi fengið kennslu í pví að gera vopnaða uppreisn (bls. 94-95). En pessi ályktun stenst ekki skoðun. Í fyrsta lagi er ekki hægt að gefa sér að námskrá einnar deildar sé jafnframt námskrá alls skólans. Hver deild (eða sektor) skólans, en peim var skipt eftir málsvæðum, hafði sína eigin námskrá og námsefni. İ öðru lagi, og petta skiptir meira máli, er hér ekki um verklegt nám í vopnaðri uppreisn að ræða, sem sjá má á upptalningunni, par sem einungis skotfimi felur í sér eiginlega verklega pjálfun. Hér er pví frekar um hlutverkaleik að ræða par sem nemendur fara í gegnum verkefni með pví að ræða aðstæður og aðferðir. Sá skilningur sem slík vinna skapar er að sjálfsögðu mikilvægur fyrir greinandann hverju sinni, flokksstarfsmanninn eða flokksleiðbeinandann, en kemur ekki í stað raunverulegrar pjálfunar.

Ole-Martin Rønning rekur stuttlega í doktorsritgerð sinni að framan af hafi Dalton aðferðin svokallaða verið notuð til að skipuleggja kennslu flokkskólanna. Aðferðin, sem er upprunnin í Bandaríkjunum, var vinsæl á pessum tíma. Hún byggði í grófum dráttum á pví að kennsla færi fram með samvinnu og samræðum nemenda sem leystu verkefni undir leiðsögn kennara frekar en að peir sætu og hlýddu á fyrirlestra. Samhengið (stríðsundirbúningur bur-

19 RGASPI 5291636 „5 Jahres Bericht der Skandinavischen Sektoren der KUNMZ,“ bls. 143 (skýrslan er aðgengileg á vefsíðu minni: http://www.jonolafs.bifrost.is/wp-content/uploads/2011/01/

529_hilt_skyrsla_32.pdf); Harry Wicks, Keeping my head, bls. 90-91.

20 Ole-Martin Rønning, Stalins elever, bls. 91.

21 Harvey Klehr ofl., The secret world of American communism, bls. 202-204. 
geisaríkja, borgarastríðið í Rússlandi, reynsla Rauða hersins) sýnir pó að hér er ekki um neina herpjálfun að ræða heldur greiningu á aðgerðum og áætlanagerð á sviði herfræði (bls. 95). Pór heldur pví fram á sömu síðu (án heimildar) að „skipulagsstarf“ sé feluheiti yfir herfræði og meðferð vopna. Рað kann að vera að svo sé, en sama heiti er í námskrám einnig haft yfir pað sem lýtur að flokksskipulagi. Pannig eru fullyrðingar Pórs einungis vangaveltur, engar heimildir styðja niðurstöður hans.

Pór segir „aðalregluna“ um nemendur Vesturháskólans hafa verið pá að peir fengju hagnýta herpjálfun utan Moskvu eftir að kennslu lauk á vorin, en Lenínskólanemendur hafi dvalið tvær vikur í æfingabúðum Rauða hersins (bls. 96). Hér er ekki rétt farið með. Rétt er að Vesturháskólinn gat sent nemendur í æfingabúðir á vegum opinberra samtaka sem önnuðust meðal annars herpjálfun óbreyttra borgara á priðja og fjórða áratugnum, en á peim tíma var mikið gert úr mögulegri innrás í Sovétríkin. ${ }^{22}$ pað er hinsvegar ekki hægt að fullyrða af peim heimildum sem Pór vísar í að allir nemendur hafa verið sendir í slíkar búðir og ekkert sem hann hefur í höndunum sýnir að Íslendingar hafi farið í pær. Vissulega er ekki hægt að útiloka pað en miklu líklegra er pó að Íslendingarnir hafi farið í sumarpjálfun sem tengdist ekki heræfingum, eins og raunin var til dæmis með Pórodd Guðmundsson og Eyjólf Árnason sem unnu með fiskimönnum norður við Murmansk og sjómönnum í Batumi sumarið 1931, eða Andrés Straumland, sem fór í eins mánaðar kynnisferð um Moskvuhérað og nærliggjandi byggðarlög ásamt samnemendum sínum í Lenínskólanum sumarið $1931 .{ }^{23}$ Hvað tveggja vikna æfingabúðirnar varðar, pá segja heimildirnar sem Pór vitnar til einungis að enskumælandi nemendur hafi verið sendir í pær í tvær vikur sumarið 1936, en ekkert um að slíkar búðir hafi verið „reglan.“ Háðuleg ummæli bandaríska fulltrúans um pessar búðir sem vísað var til hér að ofan ættu líka að benda til að pær hafi verið undantekning frekar en regla. Burtséð frá pessu er pó aðalatriðið að í öllum tilfellum er boðið upp á verklegt nám af fleira en einu tagi og pví ekki hægt að fullyrða að íslensku nemendurnir hafi fengið verklega hernaðarlega pjálfun jafnvel pó að hún hefði staðið peim til boða.

Pannig hefur sú ályktun Pórs að dæmin sem hann rekur sýni að íslenskir kommúnistar væru pjálfaðir í hernaði í Moskvu, til að vera tilbúnir með vopnin og herskipulagið pegar kallið frá Moskvu kæmi, ekkert gildi. Pó að Komintern hefði vissulega alltaf pörf fyrir fólk sem gat sent dulmálsskeyti, komið sendingum til skila og sinnt trúnaðarstörfum á alpjóðlegum vettvangi og líklegt sé að einhverjir Íslendingar hafi fengið slík verkefni, snerist pjálfun peirra í Moskvu um allt aðra hluti. Tilgangur skólanna var að pjálfa virka flokksmenn til leiðandi starfa í kommúnistaflokki sem skipulagður var eftir bolsjevískum meginreglum. ${ }^{24}$ Petta fól fyrst og fremst í sér að nemendurnir hefðu tileinkað sér réttan sögulegan skilning á rússnesku byltingunni, væru færir um að leggja réttan hugmyndafræðilegan skilning í verkefni flokksins hverju sinni og gætu skipulagt starf hans á skilvirkan hátt. ${ }^{25}$ Petta var ærið verkefni pví menn

22 Julia Köstenberger, „Die Geschichte der Kommunistischen Universität der nationalen Minderheiten des Westens (KUNMZ) in Moskau 1921-1936,“bls. 279.

23 Sjá Jón Ólafsson, Kæru félagar, bls. 64-72 og „I læri hjá Komintern,“ bls. 4-15.

24 Jón Ólafsson, Keru félagar, bls. 80-83.

25 Ole-Martin Rønning, Stalins elever, bls. 84. 
gerðu sér glögga grein fyrir pví að ef takast ætti að laða verkafólk að kommúnistaflokkum pyrfti að fara fram mikið og stöðugt áróðursstarf. Eins og sjá má af bréfaskiptum Îslendinga í Moskvu við móðurflokkinn á Íslandi árin 1930 til 1932 var áróðursstaða flokksins og ímynd hans eitt helsta áhyggjuefni peirra. ${ }^{26}$

Kommúnistar töldu sig vera raunsæja í pví að vanmeta ekki stöðu andstæðinganna. Við aðstæður eins og pær sem Kommúnistaflokkur Íslands bjó við voru verkefnin fyrst og fremst fólgin í pví að keppa við Alpýðuflokkinn um yfirráð í verkalýðsfélögum. Um pað vitna bréfaskiptin við Komintern glögglega. Um leið purfti flokkurinn að verja starfsemi sína gagnvart mögulegum njósnum og afskiptum annarra flokka með pví að halda ákveðinni leynd yfir henni. Aðferðirnar sem beitt var til pessa voru teknar mjög alvarlega og hétu einu nafni „konspiration.“ Pað sést á skýringu Pórs á pessu hugtaki að hann áttar sig ekki fyllilega á pessum grunnpætti kommúnísks flokksstarfs. Bókstaflega pýðir konspiration samsæri. Í tungutaki kommúnistaflokka á fjórða áratugnum var pað hinsvegar haft yfir aðferðirnar sem beita átti til að villa um fyrir pólitískum andstæðingum og tryggja að peir gætu ekki áttað sig á áformum kommúnistaflokksins eða einstakra sella hans hverju sinni. Pór heldur hinsvegar að konspiration sem námsgrein vísi til pjálfunar í að skipuleggja samsæri kommúnista gegn auðvaldsríkjunum (bls. 94). ${ }^{27}$

Pannig virðist umfjöllun Pórs um meint hernaðarnám Îslendinga í Moskvu vera sambland af misskilningi og rangtúlkunum heimilda. Tilgangurinn með pví að senda efnilega flokksmenn til Moskvu í læri var ekki að safna í vopnfæra bardagasveit heldur að veita verðandi leiðtogum og lykilstarfsmönnum flokksins hugmyndafræðilega pjálfun og innrætingu. Hlutverk peirra var að skipuleggja starf flokksins og sannfæra aðra um gildi kommúnistahreyfingarinnar auk pess auðvitað að halda við hinni einlægu aðdáun á öllu sovésku sem hlaut að einkenna góðan kommúnista.

\section{Bylting á Alpingishátíð, leynilegt bardagalið og pingrof}

Jens Figved var ötulastur Íslendinganna í Moskvu á árunum 1930 til 1932 að halda tengslum við félagana heima. Í febrúar 1930, en pá var hann enn eini Îslendingurinn í borginni, sendi hann Brynjólfi Bjarnasyni langt bréf par sem hann kvartaði meðal annars yfir litlum áhuga Kominternforystunnar á Íslandi. Í bréfinu hvetur hann félagana á Íslandi líka til að láta meira á sér bera. Hann skýtur peirri hugmynd að Brynjólfi að nokkrir flokksfélagar gætu hæglega hertekið ræðustólinn á Alpingishátíðinni og haldið prumandi ræðu yfir mannfjöldanum. Einnig verði að dreifa flugritum á erlendum málum, svo erlendir gestir sjái að á Íslandi eru líka kommúnistar. „Einhvern djöfulinn verðum við að gera“ segir Jens. Pór er afar alvarlegur yfir pessari uppástungu og segir Jens hafa hvatt „til ofbeldis á væntanlegri Alpingshátíð á pingvöllum“ (bls. 148). Sjálfsagt má halda pví fram að hér sé um að ræða hvatningu til skipulagðs ofbeldis og jafnvel byltingartilraunar á Alpingishátíð. Eðlilegri og einfaldari túlkun er bó

26 Sjá til dæmis bréf Jens Figved til flokksforystunnar á Íslandi, 10. júní 1931, RGASPI 529 1 633, bls. 13, 22.

27 Brigitte Studer og Berthold Unfried, Der stalinistische Parteikader, bls. 17. 
að setja hugmyndina í samhengi við áætlun um að láta á sér bera. Jens hélt jafnvel að með lítilli aðgerð á Alpingishátíðinni gætu íslensku kommúnistarnir vakið heimsathygli. ${ }^{28}$

Greining Pórs á uppástungu Jens er í samræmi við lestur hans á öðrum sambærilegum heimildum par sem viljinn til að sjá munstur samsæris um skipulögð ofbeldisverk og valdatöku, verður sterkari allri skynsemi. Í bréfi Jens Figved sem hann skrifar fyrir hönd Îslendingahópsins í Moskvu vorið 1931, og áður var nefnt, fordæmir hann harðlega áform sem peir hafa heyrt af um að stofna leynilegt bardagalið flokksmanna undir forystu Jafets Ottóssonar, sem pá hafði nýlega verið rekinn úr námi í Moskvu og sendur heim. Jens bendir á að pað sé ástæðulaust að stofna ólöglegan félagsskap. Ef kommúnistar vilji pjálfa lið sé eðlilegast að pað starfi fyrir opnum tjöldum eins og ípróttafélög. Hann hefði getað bætt pví við að á pessum tíma voru fleiri flokkar og samtök með nokkurskonar bardagalið, kommúnistar væru pví ekki að skera sig úr með stofnun slíks liðs, enda var Varnarlið verkalýðsins stofnað nokkru síðar. ${ }^{29}$

Af orðum bréfsins er augljóst að Jens er ekki að ráðleggja félögum sínum, og paðan af síður að skipa peim, að stofna bardagasveit, aðeins að benda á að slík sveit, ef ætlunin er að stofna hana, eigi að starfa fyrir opnum tjöldum. Lykilatriði í bréfi Jens er pað sem hann nefnir „smáborgaralegan sportradikalismus“. Flokksskólanemarnir voru að eigin áliti ábyrgir flokksmenn, ekki áflogaseggir eða múgæsingamenn. Pessvegna áttu peir að hugsa um pað verkefni sitt öðru fremur að vinna verkalýðinn á sitt band. Ólögleg bardagasveit væri ekki líkleg til pess. Jens skrifar: „Ьаð hlýtur að komast upp ... að kommúnistar séu farnir að ,koma upp rauðum her’ og allir borgarar hvetja lýðinn til pess að berja niður pennan ófögnuð.“ Jens taldi, eins og félagar hans í Moskvu almennt, að skipulag flokksins og starfsemi ætti að miða að pví að auka áhrif hans meðal verkalýðsins. Рað krafðist pess að menn héldu aftur af peim einstaklingum sem harðast vildu ganga fram og stöðvuðu „sportradikalistana.“ Pessvegna mátti heldur ekki láta ótrausta einstaklinga eins og Jafet taka að sér leiðandi störf í flokknum.

Að sjálfsögðu fordæmir Jens ekki beitingu ofbeldis almennt, en bréfið sýnir að KFÍ bar ekki nein skylda til pess að stofna ólöglega bardagasveit. Pór heldur pví hinsvegar fram að pessi ummæli Jens í bréfinu staðfesti að flokkurinn hafi verið skyldugur til að stofna slíka sveit og með bréfinu sé Jens að hamra á pessum skyldum flokksins (bls. 148, 151, 154). Hér er pví um að ræða túlkun á heimild sem gengur pvert gegn peim skilningi á merkingu hennar sem virðist augljós pegar bréfið er lesið. Nú skyldi maður ekki útiloka að bréf sem virðist pýða eitt, pýði eitthvað allt annað pegar betur er að gáð. En Pór reynir hvorki að skýra né réttlæta pessa undarlegu túlkun sína heldur hamrar á henni eins og hún blasi við og sanni par að auki staðhæfingar hans um að KFÍ hafi borið skylda til að stofna vopnaða bardagasveit.

Pór gerir mikið úr liðstyrk og forystu Varnarliðs verkalýðsins sem hafi á tímabili verið fjölmennara en lögreglan í Reykjavík. Pannig hafi Kommúnistaflokkur Îslands um skeið í raun lotið forystu pjálfaðra byltingarmanna sem töluðu um vopnaða uppreisn og stefndu að pví að gera byltingu með fulltingi „einræðisstjórnar í Moskvu“ (bls. 243-246). En vandinn er sá að fullyrðingar sínar byggir Pór allar á sömu fátæklegu og í sumum tilfellum pversagnakenndu heimildum. Hann hefur ekkert í höndum sem tengir Varnarlið verkalýðsins við Komintern.

28 Sjá Jens Figved til Brynjólfs Bjarnasonar, 1. febrúar 1930. Lbs 26 NF. Gögn Brynjólfs Bjarnasonar. 29 Bréf Jens Figved til flokksforystunnar 10. júní 1931. RGASPI 529 1 633, bls. 13, 22. 
Pessvegna verður hann alltaf að reiða sig á heimildir sem hann er sannfærður um að hljóti að koma fram síðar, en hann bindur að pví er virðist miklar vonir við að ímyndaðar heimildir hans sé að finna í skjölum Alpjóðasamskiptadeildar Kominterns, OMS, sem áður var nefnd (sjá bls. 103-106). Rétt er pó að benda á að ólíklegt er að heimildir um flokksstarfið á Íslandi sé að finna hjá peirri deild Kominterns par sem Alpjóðasamskiptadeildin hafði ekkert hlutverk við stýringu eða skipulagningu aðildarflokka Kominterns. Verkefni hennar voru annars eðlis. Bréf íslensku flokksforystunnar til Kominterns benda til að tilvist Varnarliðs verkalýðsins hafi ekki einu sinni verið bundin neinu samráði við Komintern. Pannig segir til dæmis Einar Olgeirsson í bréfi til Norðurlandaskrifstofu (p. Skandinavisches Ländersekretariat) sumarið 1932 að KFÍ starfræki slíkt varnarlið í samvinnu við Sósíaldemókrata eins og til að skýra fyrirbærið fyrir Norðurlandaskrifstofunni. Af pví bréfi verður svo sem engin ályktun dregin, en fyrirmælin um stofnun Varnarliðs verkalýðsins sem Pór klifar á, eru einfaldlega ekki komin fram og ekkert bendir til að slík fyrirmæli muni koma fram. ${ }^{30}$

Vorið 1931 var mjög róstusamt í Reykjavík, ekki síst í seinni hluta aprílmánaðar eftir að Tryggvi Pórhallsson forsætisráðherra hafði rofið ping til að koma í veg fyrir að sampykktar væru breytingar á kosningalögum sem hefðu komið sér illa fyrir flokk hans Framsóknarflokkinn. Skömmu áður, eða um miðjan mars, hafði Stjórnmálaskrifstofa Kominterns (p. Politsekretariat) sent Íslendingunum bréf með viðbrögðum við aðgerðaáætlun KFÍ sem sampykkt hafði verið á stofnpingi flokksins í nóvember 1930. Í bréfinu er að finna ítarlega umfjöllun um einstök atriði í stefnu flokksins og áætlunum. Stjórnmálaskrifstofan taldi Íslendingana pó ekki átta sig nægilega á styrk innlendrar borgarastéttar en tengja baráttu sína um of við danskt og breskt auðmagn og yfirráð. ${ }^{31}$ Tekið er undir margt í aðgerðaáætlun Íslendinganna ekki síst pað markmið peirra að flokkurinn verði leiðandi afl í verkalýðsbaráttu innan lands. ${ }^{32}$

Pór fullyrðir að Komintern hafi á pessum tíma gefið Íslendingunum fyrirmæli um að beita lögreglu hörku í aðgerðum sínum, en pessa niðurstöðu sína byggir hann pó ekki á bréfaskiptunum parna um vorið heldur á bréfi sem Stjórnmálaskrifstofan sendi Íslendingunum talsvert síðar eða í nóvember. Í pví er farið yfir atburði ársins og Íslendingarnir gagnrýndir fyrir að hafa ekki tekið pá forystu í verkalýðsbaráttunni sem peir höfðu ætlað sér í byrjun. Bréfið er dagsett 23. nóvember 1931 en innihald pess er fyrst og fremst samantekt og lýsing á öðru bréfi sem sent hafði verið viku áður og var formleg og ítarleg úttekt á starfi flokksins. ${ }^{33}$ Í stað pess að afla sér tiltækra heimilda um Kominternfyrirmæli vorið 1931 fer Pór pá leið að draga ályktanir um fyrirmæli Kominterns af pessari stuttu samantekt og kemst að peirri niðurstöðu að Komintern hljóti að hafa gefið Íslendingunum skipanir um að beita lögregluna „miklu grófara ofbeldi“ en fyrr (bls. 168). Hann les pví bréf Stjórnmálaskrifstofunnar á

30 Einar Olgeirsson til ónefnds viðtakanda hjá Komintern 13. júlí 1932. RGASPI 49517720 bls. 71a.

31 Politsekretariat, An das ZK der KP Islands, 13. mars 1931. RGASPI 4954 108, bls. 48-50.

32 Sama heimild, bls. 44-45.

33 Politsekretariat EKKI an das Zentralkommittee der KP Islands, 15. nóvember 1931. RGASPI 495 3294 , bls. 247-254. Í pessu bréfi komu fram öll helstu fyrirmæli Kominterns um starf Íslendinganna, enda var oft vísað til pess síðar og pá jafnan talað um „nóvemberbréfið.“ 
svipaðan hátt og bréf Jens Figveds fyrr, pað er úr samantekt á umfjöllun og gagnrýni á flokkinn ályktar hann að tiltekin fyrirmæli og skipanir hljóti að hafa verið gefnar fyrr á árinu og bréfið sé skrifað í peim tilgangi að snupra Îslendingana fyrir að hafa ekki hlýtt peim, eða ekki farið nægilega vel eftir peim. ${ }^{34}$

Komintern sendi íslensku kommúnistunum regluleg fyrirmælabréf (p. Direktiv) á fyrstu árum flokksins. Рað var Stjórnmálaskrifstofa sambandsins sem hafði petta hlutverk en í pví og á Norðurlandaskrifstofu Kominterns voru starfsmenn sem fylgdust með Íslandi og önnuðust regluleg tengsl við íslensku kommúnistana. Í bréfum pessum er brýnt fyrir Îslendingunum að koma fram sem forystuafl í verkföllum og vinnudeilum, enda voru pær vettvangur verkalýðsbaráttunnar á tímum kreppunnar. Komintern hvetur pá til að sýna yfirvöldum hörku, en slík hvatning felur ekki í sér fyrirmæli um að beita grófu eða skipulegu ofbeldi pótt heitt væri í kolunum og lítið pyrfti út af að bera til pess að slagsmál brytust út par sem verkföll stóðu yfir. Forysta kommúnista sem peir lögðu sig fram um að ná við slíkar aðstæður fólst fyrst og fremst í pví að peim tækist að sýna festu og ábyrgð og hefðu pað umfram sósíaldemókrata að peir væru aldrei tilbúnir til að svíkja hagsmuni albýðunnar fyrir samninga við yfirvöldin. ${ }^{35}$

Bréf Stjórnmálaskrifstofunnar sem Pór hefur undir höndum fjallar meðal annars um aðgerðir í tengslum við verkfallsaðgerðir í byrjun ársins, átök tengd peim og pingrofinu í apríl. Í bréfinu segir:

Í vetur og vor á pessu ári hefur brotist út hrina verkfalla sem að mestu leyti var stjórnað af umbótasinnum og miðjumönnum og var brotin á bak aftur. [...] Starf liðanna (p. Fraktionsarbeit) í verkalýðsfélögum var ákaflega veikt. Nokkrar aðgerðir atvinnulausra voru skipulagðar af kommúnistum í höfuðborginni Reykjavík. En pegar leiðtogar kommúnista stöðvuðu mótmælagöngu gegn fyrirhuguðum handtökum frammi fyrir litlum hópi lögreglumanna og lýstu m.a.s. hugsanlegri tvístrun á lögregluliðinu sem „ögrun“ og „uppreisn," lýstu jafnaðarmenn meðal verkamanna pví yfir að erfitt væri að greina muninn á jafnaðarmannaflokknum og kommúnistaflokknum. Sú lagatæknilega afstaða birtist reyndar einnig í pví að Kommúnistaflokkur Îslands hélt enga fundi og stóð ekki fyrir neinum kröfugöngum 25 . febrúar vegna banns dómsmálaráðherra. ${ }^{36}$

Nú er vitanlega hægt að hafa fleiri en eina skoðun á pví hvernig túlka beri petta tiltekna skjal, en svo mikið er víst að pað er hvorki hægt að skilja pað sem fyrirmæli um gróft og skipulagt ofbeldi né á pann veg að fyrirmæli hljóti að hafa verið gefin áður um slíkt. Hér er um að ræða mat Stjórnmálaskrifstofu framkvæmdanefndarinnar á aðgerðum sem kommúnistar tóku pátt í vorið $1931 .{ }^{37}$ Engin fyrirmæli um pátttöku peirra í pessum aðgerðum hafa komið fram og sú gagnrýni Kominterns að kommúnistar hafi verið linir í framgöngu sinni gegn fámennu lögregluliði er almennt í samræmi við pá stefnu peirra og Kominterns að peir eigi að vera leið-

34 Politsekretariat, Die K.P. Islands, 23. nóvember 1931. RGASPI 49531 113, bls. 50-53.

35 Sjá til dæmis Bericht der Gewerkschaftskommission der K.P. Islands. Der Einfluss der K.P in den isländischen Gewerkschaften. Undirritað af Brynjólfi Bjarnasyni, móttekið í Moskvu 27. júní 1932. RGASPI 495177 20, bls. 25-30.

36 Die K.P. Islands. RGASPI 49531 113, bls. 52.

37 Framkvæmdanefnd Kominterns (p. Exekutivkomittee der Kommunistischen Internationale, skammstafað $E K K I)$ var æðsta yfirvald sambandsins á milli Kominternpinga. Stjórnmálaskrifstofan annaðist daglegan málarekstur. 
andi í mótmælaaðgerðum. Ummæli Stjórnmálaskrifstofunnar einkennast af peirri afstöðu Kominterns að kommúnistum beri að leggja höfuðáherslu á að vinna fjöldann á sitt band, peirri trú að verkalýðurinn sé að verða róttækari og mikilvægi pess að sýna fram á skýran greinarmun kommúnista og sósíaldemókrata (sósíalfasista). Gagnrýnin beinist að pví að kommúnistar hafi hætt aðgerðum að ósk yfirvalda; peim er ekki álasað fyrir að hafa látið undir höfuð leggjast að ganga milli bols og höfuðs á lögreglumönnunum. Sé pað ætlun Pórs að sýna fram á mikilvægi hins ósagða í fyrirmælunum krefst pað sérstaks rökstuðnings. Рað blasir engan veginn við af peim texta sem Pór styðst við að hann „sanni“ að Komintern hafi krafist pess að kommúnistar beittu grófu og skipulögðu ofbeldi.

Pessi prjú dæmi sem ég hef rakið stuttlega, gefa ágæta mynd af pví hvernig Pór rökstyður kenningu sína í bókinni. Hann reynir að lesa pað út úr hinum takmörkuðu heimildum sínum sem sannfæring hans segir að hljóti að vera rétt, frekar en að hann fylgi peirri skyldu fræðimannsins að hafa pað sem sannara reynist og móta niðurstöður sínar eftir heimildunum. Pað má vissulega hafa samúð með tilraunum Pórs til að halda pví fram að íslenskir kommúnistar hafi beitt skipulegu ofbeldi hér á landi eftir fyrirmælum frá Moskvu pegar litið er til pess orðfæris sem einkennir stjórnmálabaráttu pessa tíma auk peirrar staðreyndar að átök væru hörð á kreppuárunum. En orðfærið eitt er ekki til marks um skipulegar áætlanir um valdatöku. Ekkert í samskiptum íslensku kommúnistanna og Kominterns bendir til annars en að stundarmarkmið hinnar pólitísku baráttu hafi verið að styrkja stöðu kommúnista gagnvart öðrum pólitískum öflum. Að sjálfsögðu var bylting lokamarkmið Kommúnistaflokks Íslands eins og annarra aðildarflokka Kominterns. En forystumenn íslenskra kommúnista, rétt eins og forystumennirnir í Moskvu, gerðu sér grein fyrir pví að valdataka væri óraunhæft markmið við pólitískt ástand fjórða og fimmta áratugarins. Нvað sem leið lokatakmarki peirra og peim stuðningi við valdbeitingu sem pað óhjákvæmilega fól í sér skapaðist aldrei pað hættuástand sem Pór virðist halda að hafi verið viðvarandi allan fjórða áratuginn og jafnvel lengur.

\section{Hollusta við Sovétríkin}

Fullyrðingar Pórs um byltingarhættuna byggja sem fyrr segir fyrst og fremst á hugmyndum hans um hernaðarpjálfunina sem hann telur að íslensku flokkskólanemendurnir hafi hlotið í Moskvu. En hún byggir líka á sovéthollustunni sem einkennt hafi kommúnistahreyfinguna. Nú er pað óumdeilt að sovéthollusta var kjarninn í kommúnísku flokksstarfi á fjórða áratugnum og útilokað að vera kommúnisti öðruvísi en að vera um leið tilbúinn til að verja og skýra öll orð og gerðir sovétstjórnarinnar. En Pór tekur sovéthollustuna einu skrefi lengra og fullyrðir að íslenskir kommúnistar hafi „oft lýst pví yfir að peir ætluðu að koma Sovétríkjunum til hjálpar ef styrjöld hæfist, “Einar Olgeirsson hafi lýst pví yfir að ef auðvaldsríki réðust á Sovétríkin myndu íslenskir kommúnistar pegar hefja borgarastyrjöld á Íslandi (bls. 402). Hann segir pá hafa heitið Sovétríkjunum liðsinni í styrjöld opinberlega (bls. 397) og hamrar á pví sem hann kallar „spádóm Leníns“ um að Ísland yrði mikilvæg flugbækistöð í átökum Sovét-Evrópu og Ameríkuauðvaldsins (bls. 395). Pannig slær Pór pví föstu að kommúnistar á Íslandi hefðu gripið til vopna gegn íslenskum yfirvöldum ef pess hefði verið krafist í Moskvu. 
Hann heldur pví meira að segja fram að yfirlýsing Einars Olgeirssonar hafi verið í fullu gildi sem opinbert loforð eftir að Kommúnistaflokkurinn var lagður niður. Pó er umrædd yfirlýsing sem Pór vitnar til aftur og aftur í bók sinni aðeins lokasetning í grein sem skrifuð er í tímaritið Rétt árið 1930 en par segir Einar: „Og brjótist stríðið út pá fellur pað kommúnistum í skaut að hefja borgarastyrjöldina gegn auðvaldinu alstaðar par sem pað fer í stríð við Rússland. “ ${ }^{38}$ Í fyrsta lagi er hægt að skilja Einar svo að aðeins kommúnistum í ríkjum sem fari í stríð við Sovétríkin beri að snúast á sveif með peim gegn eigin stjórnvöldum. İ öðru lagi er hæpið að fullyrða út frá almennri yfirlýsingu af pessu tagi að ljóst sé að íslenskir kommúnistar hefou, ef á hefði reynt, staðið með Sovetríkjunum, jafnvel gegn eigin pjóð, í átökum.

Nú má fallast á pað með pór að yfirvöld á fjórða áratugnum, pólitískir andstæðingar kommúnista og fjölmiðlar pessara tíma, hafi átt að taka slíkar yfirlýsingar alvarlega. En pað pýðir ekki að sagnfræðingar í dag hljóti að lesa pær með sama hætti. Getum við í dag dregið ályktanir um mögulegar aðgerðir kommúnista í stríði út frá yfirlýsingum af pessu tagi sem gefnar eru í ræðum eða blaðagreinum og eru settar fram í áróðurstilgangi? Pór svarar slíkri spurningu að hluta til sjálfur í lok bókar sinnar pegar hann bendir á að fánýtt sé að spyrja hvað gerst hefði ef mál hefðu próast með öðrum hætti en pau gerðu (bls. 428). En með slíku svari kemst hann ekki hjá pví að gera lítið úr samsæriskenningu sinni, pví hún byggir jú að stærstum hluta á tilraunum til að segja fyrir um pað sem kommúnistar á Íslandi hefðu gert ef mál hefðu próast með öðrum hætti en pau gerðu. Vandi Pórs er sá að tilvist stjórnmálaafls sem er fjandsamlegt ríkjandi pjóðskipulagi og telur að pví verði bylt með valdi í fyllingu tímans dugir ekki til að sýna fram á að petta stjórnmálaafl hafi nokkurn tímann komist nálægt pví að telja stundina runna upp til slíkra aðgerða.

Meira að segja eftir Gúttóslaginn í nóvember 1932, en Pór álítur að pá hefðu kommúnistar getað tekið völdin, er ljóst að peir sáu stöðu sína ekki með sama hætti. Í bréfi sem Brynjólfur Bjarnason skrifaði miðstjórninni kemur fram að aðgerðir hafi farið úr böndunum og kommúnistar getað nýtt sér pað. Brynjólfur segir ljóst að lögreglan sé pví mjög hrædd við kommúnista. Hann var sér hinsvegar fyllilega meðvitaður um að prátt fyrir pessa stöðu var enginn raunhæfur möguleiki á valdatöku. Рað var vegna pess að Brynjólfur var, eins og flestir félaga hans, raunsær. Jafnvel pótt harðsnúinn hópur manna ætti í fullu tré við lögregluna á götum úti, fór pví fjarri að flokkurinn hefði burði til að taka völdin í landinu. ${ }^{39}$

Pað má skilja ótta stjórnvalda við Kommúnistaflokkinn á átakaárum kreppunnar. En jafnvel pó að sá ótti sé skiljanlegur og jafnvel réttlætanlegur styður ekkert pá skoðun að hætta hafi verið á valdatöku hans. Рað hlýtur að vera lykilatriði í greiningu á stjórnmálaástandi kreppunnar.

\section{Samræður um pólitík: Brynjólfur í Moskvu 1932}

Fyrstu árin eftir að Kommúnistaflokkur Îslands var stofnaður árið 1930 voru samskipti við höfuðstöðvarnar í Moskvu mjög tíð enda gert ráð fyrir pví að stefna flokksins og aðgerðir

38 Einar Olgeirsson, „Straumhvörf,“ bls. 236.

39 Brynjólfur Bjarnason til Richards Mehring 3. desember 1932, RGASPI 495177 20, bls. 82-86. 
væru ræddar í paula innan Norðurlandaskrifstofu Alpjóðasambandsins. En pað samráð sem KFÍ bar að hafa við Komintern vegna aðildar sinnar að sambandinu fól pó ekki í sér að flokkurinn tæki möglunarlaust við fyrirskipunum pess. Forystumenn flokksins tóku við fyrirmælum og ráðleggingum frá Moskvu, en pað kom ekki í veg fyrir að flokkurinn færi líka eigin leiðir og andmælti tillögum Norðurlandaskrifstofunnar. Dæmi um petta er ferð Brynjólfs Bjarnasonar til Moskvu sumarið 1932. Par var tekið á móti honum hjá Komintern eins og venja var um flokksleiðtoga sem heimsóttu höfuðstöðvarnar og hann flutti skýrslu um starf flokksins. Orðrétt afrit munnlegrar skýrslu Brynjólfs er varðveitt í safni Kominterns og hún gefur ágæta mynd af peim umræðum sem forystumenn KFÍ áttu í Moskvu á pessum tíma. ${ }^{40}$

Brynjólfur byrjar á pví að gefa yfirlit yfir stöðu efnahagsmála og stjórnmálaástandið á Íslandi og í framhaldi af pví fjallar hann um starf Kommúnistaflokksins. Hann er sumpart að bregðast við nóvemberbréfinu sem KFÍ hafði borist frá Stjórnmálaskrifstofu Kominterns í lok árs 1931 og nefnt var áður, par sem flokknum höfðu verið gefin ýmis fyrirmæli um starfið næsta misserið. Brynjólfur tekur fram að flokknum hafi ekki borist bréfið fyrr en eftir að ping hans hafði verið haldið, en áður höfðu forystumenn KFÍ farið fram á pað við Komintern að fulltrúi yrði sendur til Îslands til að vera viðstaddur flokkspingið. Peirri beiðni var hafnað en í staðinn fékk flokkurinn ítarlega greiningu Stjórnmálaskrifstofunnar á starfinu fyrsta árið auk fyrirmælanna um framhaldið. ${ }^{41}$

pessvegna fer Brynjólfur næst yfir pau atriði sem sérstaklega höfðu verið nefnd í nóvemberbréfinu. Hann fellst á sumt sem fram kemur í bréfinu en ekki annað. Hann tekur til dæmis undir gagnrýni á flokkinn vegna kosningabaráttu hans sumarið 1931, en Komintern taldi margt hafa farið úrskeiðis í henni. Ekki síst hafði verið bent á að eitt slagorð flokksins sem gerði ráð fyrir að velja pyrfti á milli umbóta og byltingar samræmdist ekki réttri stefnu, par sem pað væri talið geta farið saman að stefna að byltingu og vinna að umbótum. ${ }^{42}$ Hinsvegar sá Brynjólfur ástæðu til að mótmæla peirri staðhæfingu Kominternforystunnar að íslensku kommúnistarnir hneigðust til að vanmeta borgarstéttina á Íslandi og væru uppteknari af áhrifum bresku krúnunnar á Íslandi heldur en af yfirráðum Dana, sem að áliti Kominterns átti að vera meginviðfangsefni í pjóðfrelsisbaráttu kommúnista. ${ }^{43}$

Umdeildustu atriðin í starfi Kommúnistaflokksins snerust pó um framgöngu flokksins og flokksmanna í verkföllum og vinnudeilum. Komintern prýsti á um að kommúnistar tækju afgerandi forystu pannig að peim væri pakkað ef árangur næðist í deilum við atvinnurekendur og yfirvöld. Kommúnistar höfðu látið mjög til sín taka í vinnudeilum í Vestmannaeyjum árið áður og töldu sig hafa náð par miklum árangri. Í nóvemberbréfinu er pví hinsvegar haldið fram að peir hafi verið of linir og pví misst af tækifæri til að vinna fullnaðarsigur. Pessu er Brynjólfur ósammála. Hann segir:

Við erum gagnrýndir fyrir að hafa nálgast atburðina á rangan hátt og gerst sekir um hentistefnu með slagorðinu „Beygið stórbokkana.“ Fullyrt er að baráttan í [Vestmannaeyjum] sé dæmi um

40 Genosse Bjarnason: Über Island, 27. júní. RGASPI 49518 940, bls. 2-30.

41 Sjá Brief an die ZK der KPI, 15. nóvember 1931, RGASPI 49531 113, bls. 51.

42 Genosse Bjarnason: Über Island, 27. júní. RGASPI 49518 940, bls. 12.

43 Sama heimild, bls. 11. 
pessa röngu hentistefnunálgun. Petta er að mínu mati alrangt. Рað var aldrei neinn möguleiki á pví að 100\% árangur næðist í verkfallinu. ${ }^{44}$

Í Vestmannaeyjadeilunni hafði vandinn verið sá að lausnin krafðist stuðnings Alpýðusambandsins. „Ættum við virkilega“ spyr Brynjólfur „að hafna peirri leið að knýja Alpýðusambandið til að setja sína vél í gang til að styðja verkföllin í sjávarporpunum? ${ }^{45}$ Pannig einkennir heilbrigð skynsemi málflutning Brynjólfs. Hann telur sig greinilega geta rökrætt við félaga sína hjá Komintern, gerir mikið úr reynslu peirra og ráðum, en er líka tilbúinn til að mótmæla niðurstöðum peirra ef hann er peim ósammála. Í lok samtalsins veltir Brynjólfur vöngum yfir nokkrum knýjandi spurningum og óskar svara við peim. Hann spyr: Hvað er rétt að „við“ (íslenskir kommúnistar) gerum ef Îsland verður með óbeinum hætti pátttakandi í stríði gegn Sovétríkjunum, til dæmis sem birgðastöð? Er rétt að berjast fyrir pví að Ísland taki upp viðskipti við Sovétríkin? Gætu slík viðskipti valdið ranghugmyndum peirra sem binda miklar vonir við að Sovétríkin geti hjálpað Íslandi upp úr kreppunni? Hvað ef raunverulegt byltingarástand skapaðist á Íslandi? Gæu Íslendingar selt megnið af framleiðslu sinni til Sovétríkjanna og einskorðað innflutning sinn við pau? Hvað eiga íslenskir kommúnistar að gera ef hungursneyð verður vegna atvinnubrests í einstökum byggðarlögum? Er rétt að yfirtaka atvinnutækin? Brynjólfur óttast að slíkt myndi leiða kommúnista í blindgötu og pessvegna væri ekki ólíklegt að Alpýðuflokksmenn myndu styðja slíka kröfu til að einangra kommúnista. ${ }^{46}$ Og svo framvegis. Рað sem er áberandi hér eru spurningarnar. Sumum peirra svaraði Komintern í bréfum og fyrirmælum sem flokknum bárust í kjölfar pessa fundar, einkum í löngu fyrirmælabréfi sem Íslendingunum var sent í ágúst, öðrum var látið ósvarað. ${ }^{47}$

Í bréfinu er gagnrýnin á flokkinn sem sett hafði verið fram árið áður endurtekin. Mest áhersla er lögð á að flokkurinn beiti sér fyrir pví að koma á fót sjálfstæðri verkalýðshreyfingu par sem Alpýðusambandið hafi meiri áhuga á pví að ná samstöðu með kapítalistunum heldur en að verja hagsmuni verkalýðsins. Kommúnistar verði að sýna afgerandi forystu í skipulagi verkalýðsbaráttunnar og leiða verkalýðinn í vinnudeilum og verkföllum. Á fundinum um sumarið hafði Brynjólfur hinsvegar lýst miklum efasemdum um möguleikana á pví að stofna sjálfstæða verkalýðshreyfingu. ${ }^{48}$

Ályktanirnar sem hægt er að draga af pessum samskiptum eru ekki pær að Kommúnistaflokkur Íslands hafi fyrst og fremst viljað vera hlýðinn pjónn Kominterns og framkvæma skipanir pess möglunarlaust, heldur að forystumenn flokksins taka afstöðu til fyrirmæla Kominterns og eiga í samræðu við Norðurlandaskrifstofuna um pau og almennt um stefnu flokksins. Árin 1931 og 1932 eru tími mikilla vinnudeilna og kannski mesta pjóðfélagslega óróa sem um getur hér á landi. Sú harða pólitík sem Komintern leggur að sínum mönnum á Íslandi að taka upp er afsprengi pessara aðstæðna og um leið peirrar sannfæringar að róttækni fari stöðugt vaxandi meðal verkalýðsins og pví eigi kommúnistar að sæta færis og taka for-

44 Sama heimild, bls. 23. Deilan stóð í janúar 1931 og lauk með samkomulagi við Alpýðusambandið.

45 Sama heimild, bls. 24.

46 Genosse Bjarnason: Über Island, 27. júní. RGASPI 49518 940, bls. 26-29.

47 To the CC of the CP of Iceland, 12. desember 1932, RGASPI 4954201 bls. 117-140.

48 To the CC of the CP of Iceland, bls. 132-133; Über Island, RGASPI 49518 940, bls. 18. 
ystuna. Hinsvegar er hvergi minnst á hernað eða ofbeldi í peim ráðleggingum og fyrirmælum sem Komintern sendi til Îslands að nema pá pegar pví er haldið fram að ríkisvaldið eða flokkar andstæðir kommúnistum séu að vopnast. Í bréfum Íslendinganna kemur hinsvegar fram að peir séu sakaðir um að safna vopnum. Pannig skrifar Einar Olgeirsson í júlí, eftir að Brynjólfur er farinn frá Moskvu, að Varnarlið verkalýðsins, sem skipulagt sé „með sósíaldemokratískum verkamönnum “ sé sakað um að bera vopn. Í bréfinu lýsir hann mótmælum pann 7. júlí í Reykjavík, sem mestu mótmælaaðgerðum sem farið hafi fram í Reykjavík. „Fjandsamleg öfl“ hafi purft að halda sig til hlés og ekki porað að láta á sér kræla. „Við áttum göturnar petta kvöld, “ segir Einar; íslenska borgarastéttin hafi orðið verulega skelfd. ${ }^{49}$

Fyrirmæli Kominterns eru sannarlega ekki til pess fallin að stöðva eða draga úr ofbeldi, en pau skipa hvorki fyrir um pað, né stýra pví. Đað er lítil innistæða fyrir peirri fullyrðingu pórs Whitehead að pær óeirðir og slagsmál sem brutust út í kringum vinnudeilur á pessum tíma eigi rætur að rekja til ráðabruggs í Moskvu. Á sama hátt benda engar heimildir um petta samband til pess að fyrrverandi nemendur úr Vesturháskólanum eða Lenínskólanum hafi haft sérstakt hlutverk við að leiða eða skipuleggja mótmæli eða aðgerðir í verkföllum. Í bréfi sem Brynjólfur sendir ónefndum félaga hjá Norðurlandaskrifstofu Kominterns í október sama ár kemur fram hvert hlutverk Jens Figved, sem dvalist hafði prjú ár í Moskvu, var pegar hann var kominn heim aftur. Fyrst var hann sendur til flestra flokksdeilda um landið til að kynna ályktanir stjórnmálaráðs KFÍ um starfsemi flokksins, mikilvægustu skipulagsverkefni hans, dagblað sem ætlunin væri að gefa út í stað Verklýðsblaðsins og um starfsemi kommúnískra flokksbrota. Jens var látinn aðstoða flokksdeildirnar við að gera eigin ályktanir par sem fjallað var um starfið í deildinni frá sjónarmiði sjálfsgagnrýni. Petta hafði Jens lært í Moskvu hvernig beitt er flokkslegum pumalskrúfum til að knýja fram pær hugmyndafræðilegu áherslur sem línan krafðist. Allt voru petta ályktanir sem Komintern hafði lagt mikla áherslu á að flokkurinn gerði. Brynjólfur segir hreinskilnislega að pótt ekki hafi verið um neina andstöðu að heitið geti við ályktanirnar að ræða, megi búast við pví að „hugmyndafræðilegur skýrleiki“ komi aðeins smám saman. ${ }^{50}$ pað var orð að sönnu pví að strax í nóvember byrjuðu heiftúðugar innanflokksdeilur sem næstum lögðu flokkinn í rúst árin á eftir. Pessar deilur snerust hvorki um ofbeldi eða hernað heldur um nákvæman skilning á réttri stefnu kommúnistaflokks par sem minnsta frávik frá boðaðri harðlínustefnu var brottrekstrarsök úr flokknum. Jens Figved hafði einnig verið sendur vestur á Ísafjörð til að ræða við kommúnistana par eftir að forystumaður peirra Ingólfur Jónsson, sem einnig var bæjarstjóri, hafði verið rekinn úr flokknum fyrir samstarf við Alpýðuflokksmenn. Jens var pví kominn í hlutverk eins konar innanlands Kominternfulltrúa, enda traustsins verður eins og umsögn um hann sem birt var hér að framan sýnir glögglega. ${ }^{51}$

49 Einar Olgeirsson til ópekkts viðtakanda, 13. júlí 1932, RGASPI 495177 20, bls. 71a.

50 Brynjólfur Bjarnason til ópekkts viðtakanda, 24. október 1932. RGASPI 495177 20, bls. 75-76.

51 Sama heimild, bls. 80 . 


\section{Sambandið við Moskvu eftir daga Kommúnistaflokks Íslands}

Kommúnistaflokkur Îslands var lagður niður haustið 1938 og Sósíalistaflokkurinn - sameiningarflokkur alpýðu stofnaður með klofningshópi úr Alpýðuflokknum um leið. Forystumenn kommúnista sáu petta sem taktíska aðgerð og hún var ekki umdeild í peirra röðum. Allir félagar KFÍ fluttust yfir til hins nýstofnaða Sósíalistaflokks. Flestir forystumenn flokksins voru pó á peirri skoðun að pjóðfélagsbylting, vopnuð eða óvopnuð, væri eftir sem áður lokamarkmið flokksins. Sósíalistaflokkurinn átti ekki aðild að Komintern en forystumenn hans gerðu ráð fyrir pví að áfram yrðu náin og vinsamleg tengsl við alpjóðasambandið. •að breytir hinsvegar ekki pví að eðli tengslanna var dálítið annað. Til dæmis er ekki að sjá á heimildum að Sósíalistaflokkurinn hafi nokkurntímann sent skýrslur til Moskvu um flokksstarfið eins og Kommúnistaflokkur Íslands hafði gert sem aðildarflokkur.

pór heldur pví fram að Sósíalistaflokkurinn hafi verið stofnaður eftir að sérstakt leyfi til pess hafi fengist frá Komintern. Pó hafa engar heimildir fundist um leyfið. Dvert á móti eru nær engin samskipti á milli íslensku kommúnistanna og Kominterns frá pví í ágúst 1938, er Einar Olgeirsson tilkynnir framkvæmdanefnd Kominterns að til standi að stofna flokkinn og par til Kristinn E. Andrésson kom til Moskvu og hitti yfirstjórnina vorið 1940. Einu samskiptin á pessu tæplega tveggja ára tímabili eru kveðjubréf sem fóru á milli Æskulýðsfylkingarinnar og Alpjóðasambands ungra kommúnista í Moskvu og hafa enga pólitíska pýðingu. Í Koeru félögum gat ég mér pess til, eins og Pór, að Komintern hefði gefið leyfi til stofnunar flokksins, jafnvel pótt í samtölum yfirstjórnarinnar og Íslendinganna áður hafi komið fram miklar efasemdir af hálfu Kominterns um að skynsamlegt væri að kljúfa Alpýðuflokkinn, eins og raunin varð pegar Sósíalistaflokkurinn var stofnaður. Nokkrum árum eftir að bók mín kom út fannst hinsvegar heimild sem tók af öll tvímæli um að tilkynning Einars um flokksstofnunina vakti litla hrifningu í Moskvu og rætt var um leiðir til að koma í veg fyrir að Íslendingarnir gerðu alvöru úr henni. Petta var minnisblað Wilhelms Florin, sem fór með málefni Norðurlanda hjá Komintern, til Georgís Dimitrov, forseta sambandsins. Í minnisblaðinu eru settar fram hugmyndir um leiðir til að koma skilaboðum til íslensku kommúnistanna og fá pá ofan af áformum sínum. ${ }^{52}$

Petta minnisblað purfti bó í raun ekki að koma á óvart par sem yfirstjórnin hafði oftar en einu sinni lýst pví yfir við Îslendingana að hún teldi óráđlegt haga samfylkingarbaráttu Kommúnistaflokksins pannig að hún gæti leitt af sér klofning Albýðuflokksins. Í minnisblaði Heinrichs Most og Ottos Kuusinen til Dimitrovs dagsettu 11. júní 1936 segir til dæmis að léleg tengsl við íslenska flokkinn hafi orðið til pess að flokkurinn hafi tekið rangan pól í hæðina í nokkrum mikilvægum málum, par á meðal í stefnunni gagnvart Alpýðuflokknum: „KFÍ fylgir hér stefnu sem í rauninni miðar að pví að kljúfa vinstri vænginn frá flokknum. “ ${ }^{53}$ Í tillögum

52 Sjá Jón Ólafsson „Komintern gegn klofningi: Viðbrögð Alpjóðasambands kommúnista við stofnun Sósíalistaflokksins, “ bls. 93-111; „Nokkur orð um ályktanir og túlkun heimilda,“ bls. 165-172, „Raunveruleiki fortíðar og eitt minnisblað,“ bls. 149-161; Pór Whitehead „Eftir skilyrðum Kominterns: Stofnun Sameiningarflokks albýðu - Sósíalistaflokksins 1937-1938,“bls. 17-55, „Eitt minnisblað og óraunveruleiki fortíðar: Svar til Jóns Ólafssonar,"bls. 175-184.

53 An den Genossen Dimitrov. Betrifft: Isländische Frage, 11. júní 1936. RGASPI 49518 1095, bls. 113-114. 
sem Komintern sendir Íslendingunum tveimur vikum síðar segir „Íslensku kommúnistarnir verða að prýsta fast á um einingu allra verkalýðs- og stjórnmálafélaga landsins í Alpýðusambandi Îslands og tala og berjast fyrir henni. ${ }^{\text {“54 }}$

Skýringin á pví að einn helsti forystumaður Kominterns lagðist gegn klofningi Alpýðuflokksins var meðal annars sú að sá hluti flokksins sem stæði eftir pegar búið væri að kljúfa gæti orðið kommúnistum skeinuhættur og komið í veg fyrir að peim lánaðist að gera samfylkingar- og pjóðfylkingarbaráttu sína trúverðuga. Petta kemur meðal annars fram í bréfi Philips Dengel, sem var háttsettur hjá Komintern, til Einars Olgeirssonar vorið 1937. Par mótmælir Dengel peirri fullyrðingu Einars í bréfi sem hann hafði sent fyrr um veturinn að leiðtogar Alpýðuflokksins hafi einangrast. Dengel bendir á að ekki sé annað að sjá en tveir priðju hlutar flokksmanna fylgi leiðtogunum að málum. ${ }^{55}$

Hér er pví staðan enn sú að Pór setur fram fullyrðingar sem hann rökstyður með getgátum einum. Nákvæmur lestur heimildanna sjálfra bendir hinsvegar til allt annarrar niðurstöðu en getgátur hans. Pór heldur pví fram að Brynjólfur Bjarnason hafi „lagt á ráðin um pað með æðstu yfirboðurum sínum að stofna hér við fyrsta tækifæri sameiningarflokk sem að nafninu til væri ekki byltingarflokkur“ (bls. 344). Hér ruglar Pór saman heimildum pví petta kemur hvergi fram í peim samræðum sem Brynjólfur átti í Moskvu 1937. •að er Einar Olgeirsson sem lýsir markmiðunum svo í tilkynningu sinni um flokksstofnunina. ${ }^{56}$ Pað gerir gæfumuninn, pví Einar er að gera sér vonir um að Kominternforystan láti sannfærast um gildi pess að stofna Sósíalistaflokkinn í ljósi pessara markmiða. Pau voru ekki umsamin fyrirfram, par sem Kominternforystan hélt ekki að flokksstofnun væri á dagskrá með pessum hætti (sjá einnig neðanmálsgrein bls. 348).

\section{Myndun Nýsköpunarstjórnarinnar}

Nú væri vissulega hægt að halda áfram að rekja samskipti Kominterns og íslenskra kommúnista, enda eru pau merkilegur kafli í stjórnmálasögu fjórða áratugarins. Ég ætla hinsvegar að halda mig við upphaflegt markmið sem er að benda á megingallana við málflutning Pórs Whitehead. Við stökkvum pví nokkur ár fram í tímann, til loka heimstyrjaldarinnar, pegar enn var talsverður vinskapur með ólíkum pólitískum öflum sem höfðu talið sig samherja í baráttunni við nasismann síðustu ár stríðsins. Víða í Evrópu áttu kommúnistar aðild að ríkisstjórnum sem myndaðar voru í stríðslok og sama átti við á Íslandi. Pór hefur í fyrri bókum sínum fjallað um pann orðróm að Sósíalistaflokkurinn hafi verið í nánu samráði við Moskvu sumarið 1944 pegar viðræður stóðu yfir um myndun ríkisstjórnar með Sjálfstæðisflokki og Alpýðuflokki sem síðar varð pekkt undir heitinu Nýsköpunarstjórnin. Ástæða pessa orðróms er einkum sú staðreynd að sovéska sendiskrifstofan sem pá var nýstofnuð virðist hafa sent og tekið við óvenju mörgum löngum skeytum petta sumar. Pór vitnar jafnan í breska sendiherrann, orðum sínum til stuðnings og gerir pað einnig nú: „Breski sendiherrann var sjálfur

54 Vorschläge zur isländischen Frage, 23. júní 1936. RGASPI 49515 102, bls. 59-62.

55 Philip Dengel til Einars Olgeirssonar 6. mars 1937. RGASPI 49515 105, bls. 27-30. Ég rek samtöl

Íslendinganna við yfirstjórn Kominterns ítarlega í „Komintern gegn klofningi,“ sjá einkum bls. 99-105.

56 Einar Olgeirsson til Kominterns, 21. ágúst 1938. RGASPI 49574 265, bls. 1-4. 
sannfærður um að Sósíalistaflokkurinn hefði í einu og öllu farið eftir fyrirskipunum frá Moskvu. Sú ályktun getur ekki talist langsótt, en meginlínan var hvort eð er skýr“ (bls. 392).

Pór endurtekur vangaveltur um samskipti við Sovétstjórnina petta sumar án pess geta upplýst nokkuð nýtt um pau. Hann heldur pví hinsvegar fram að samskipti íslenskra kommúnista við Moskvu hafi sennilega aldrei verið greiðari en eftir stofnun sovétsendiráðs í Reykjavík 1944. Petta eru sem fyrr hreinar getgátur og í litlu samræmi við tiltækar heimildir. Heimildirnar staðfesta raunar pað pveröfuga, að samskipti sendiráðsins við forystumenn íslenskra kommúnista jukust með tímanum og voru langmest á seinni hluta sjötta áratugarins og peim sjöunda. Í skjalasafni flokksins par sem finna má heimildir um samskipti við íslenska forystumenn hefur til dæmis ekki fundist eitt einasta skjal um fundi forystumanna sósíalista og Alexanders Krassilnikovs, sendifulltrúa Sovétstjórnarinnar hér á landi árið 1944. Eins og ég rek nokkuð nákvæmlega í bók minni Koru félögum, eru skýrslur úr sendiráði Sovétríkjanna frá árunum 1946 til 1948 hinsvegar fullar af gagnrýni á Sósíalistaflokkinn sem er sagður pjóðernissinnaður flokkur, og forystumenn hans hallir undir „smáborgaraleg“ viðhorf. ${ }^{57}$

Рað má vissulega berja höfðinu við steininn og halda pví fram að par sem samskiptin hljóti að hafa verið mikil árið 1944 hljóti líka að vera til heimildir um pau og skeytasendingar úr sovéska sendiráðinu sem enginn veit hvað fjalla um hljóti að hafa innihaldið fyrirmæli til sósíalista um hvernig peim bæri að haga stjórnarmyndunarviðræðum. En slíkar getgátur hafa afar lítið gildi sem innlegg í fræðilega umræðu um pessi mál. Staðreyndin er sú að ekkert er hægt að fullyrða um afskipti Sovétstjórnarinnar af pessum viðræðum, enda gætu skeytin pess vegna fjallað um mannahald og skipulag sendiskrifstofunnar eins og um stjórnarmyndunarviðræður. Frekari upplýsingar um petta munu koma á daginn pegar aðgangur fæst að dulmálsskeytum Sovétstjórnarinnar frá pessu tímabili, en slík samskipti við sendiráð eru varðveitt í skjalasafni rússneska utanríkisráđuneytisins.

Pór bendir einnig á mikilvægt atriði um áhuga Sovétstjórnarinnar á Íslandi og Îslendingum í lok stríðsins með tilvísun í skýrslu Ivans Majskíjs, sendiherra Sovétstjórnarinnar í London, en Majskíj fór fyrir nefnd sem gerði tillögur um stefnumörkun stjórnvalda um yfirráða- og áhrifasvæði eftir að heimstyrjöldinni lyki. ${ }^{58}$ Majskíj-skýrslan gerði ráð fyrir pví að Ísland yrði á bandarísku áhrifasvæði eftir stríðið, en pessi niðurstaða, sem hafði mikil áhrif á stefnu sovéskra stjórnvalda, pýddi að Sovétmenn myndu ekki seilast til áhrifa á Íslandi eins og peir gerðu í peim löndum sem peir töldu að ættu að vera innan síns áhrifasvæðis. Pví má álykta að áhugi Sovétríkjanna á Íslandi hafi verið takmarkaður í stríðslok, að minnsta kosti miklu minni en síðar varð pegar hernaðarumsvif Bandaríkjamanna jukust á Íslandi, fyrst eftir Keflavíkursamninginn sem gerður var 1946 og ennpá frekar eftir að varnarsamningurinn var gerður 1951. Pór áttar sig pví ekki á mikilvægi Majskíj-skýrslunnar, par sem hún skýrir minni áhuga Sovétstjórnarinnar á Íslandi í stríðslok heldur en á síðari árum. ${ }^{59}$

57 Sjá Jón Ólafsson, Keru félagar, bls. 155-159.

58 Sjá einnig Jón Ólafsson, Karu félagar, bls. 134; Jón Ólafsson, „Raunveruleiki hins ímyndaða,“ bls. 12.

59 раð er raunar skemmtilegt í pessu sambandi að rifja upp blaðaskrif peirra Pórs Whitehead og Björns Bjarnasonar um petta efni en peir andmæltu peirri niðurstöðu minni harðlega í greinum sínum í Morgunblaðinu að Sovétmenn hefðu litið á Ísland sem bandarískt áhrifasvæði eftir stríðið, sjá Pór Whitehead, „Voru íslenskir 
Раð verður vissulega fróðlegt að sjá hvað kemur í ljós pegar hægt verður að kynna sér dulmálsskeyti Sovétstjórnarinnar frá árinu 1944. En ekkert er hægt að fullyrða um hvort sósíalistum hafi verið fjarstýrt frá Moskvu inn í samstarf við Ólaf Thors fyrr en að pví kemur.

\section{Enn um ofbeldi}

Í peim dæmum sem ég hef fjallað um í pessari grein má glögglega sjá pá aðferðafræði sem liggur að baki ályktunum og fullyrðingum Pórs Whitehead í Sovét-Íslandi. Hann setur fram tilgátur í upphafi, tínir til heimildir sem ekki stangast augljóslega á við tilgáturnar og heldur pví svo fram að heimildirnar staðfesti pær. İ nokkrum tilfellum lítur hann einnig framhjá atriðum sem beinlínis mæla gegn tilgátum hans. Rit hans er pví lítils virði í fræðilegu samhengi. Рað lýsir fyrst og fremst eindreginni sannfæringu höfundarins, andúð hans á kommúnistum og hneykslun hans yfir andvaraleysi stjórnvalda. Pau hafi hvorki hirt um að refsa vinstrimönnum svo sem Pór hefði talið eðlilegt fyrir glæpaverk pau sem hann telur að peir hafi skipulagt og í fáeinum tilfellum framið, né byggt hér upp nægilega sterkt öryggis- og lögreglulið til að brjóta samtök peirra á bak aftur. Óneitanlega er ógnvænlegt til pess að hugsa hvers kyns harðstjórn hefði ríkt hér á landi ef stjórnvöld hefðu gripið til peirra aðgerða sem pór telur að hefðu verið eðlilegar.

Pór segir í lok bókar sinnar að „óyggjandi heimildir“ sýni að frá 1921 til 1946 hafi hugur sósíalista staðið til pess að taka völdin á Íslandi með byltingu. Ég geri ráð fyrir pví að hugur sósíalista til að gera byltingu, með einum eða öðrum hætti, hafi staðið miklu lengur en petta, ekki síður en umræðurnar um pað í peirra hópi hvort byltingin yrði gerð í áföngum eða einu lagi, hvort hún yrði vopnlaus eða vopnuð, hvernig tekið yrði á málum að henni lokinni, hverjir yrðu skotnir og hverjir ekki og svo framvegis. Ég man meira að segja eftir pví sjálfur að hafa sem nýnemi við Menntaskólann í Hamrahlíð haustið 1980 hlýtt á spekingslegar samræður nemenda, sem gengu par um ganga í mosagrænum jökkum, með alpahúpur skreyttar rauðum stjörnum, um verkefnin sem myndu blasa við eftir byltinguna. Spurningin er hinsvegar ekki hvað sagt var, pví margt var sagt, heldur hvort hætta var á ferðum. Niðurstaða mín er sú að engar heimildir, skriflegar eða munnlegar, sem hingað til hafa komið fram, gefi tilefni til að ætla að hér hafi nokkurn tímann verið hætta á valdatöku kommúnista. Peir höfðu aldrei styrk til pess að taka völdin og halda peim, ekki einu sinni árið 1932, og petta vissu peir vel. peir höfðu ekki heldur pað fylgi sem gerði peim mögulegt að hrífa fjöldann með sér í aðgerðum gegn ríkisvaldinu og pað vissu peir ennpá betur. Er hugsanlegt að sovéskur herstyrkur hefði verið sendur hingað til lands til að styðja við byltingu íslenskra kommúnista? Hugmyndin er svo fráleit að ég ætla að hlífa lesendum við bollaleggingum um hvort svo hefði getað farið.

En auðvitað er skiljanlegt að herskár málflutningur kommúnista á fjórða áratugnum veki spurningar um hvað peir ætluðu sér og hvers peir voru megnugir. Pað er sannarlega ekki ætlun mín að halda pví fram að kommúnistahreyfingin á pessum tíma hafi hafnað ofbeldi,

kommúnistar hættulegir?“ bls. 9; Björn Bjarnason, „Jón og fimmta herdeildin,“ bls. 33. Pór hefur pví loks áttað sig á um hvað Majskíj-skýrslan snerist, pótt hann átti sig ekki á áhrifunum á tengslin við íslenska sósíalista. Sjá einnig Jón Ólafsson, „Ímyndaðar herdeildir dómsmálaráðherrans, “bls. 23. 
pvert á móti. Pað var hinsvegar tekist á um hvort byltingin gæti farið fram án valdbeitingar, en Einar Olgeirsson og Kristinn E. Andrésson létu í ljós pá skoðun oftar en einu sinni, við lítinn fögnuð hinna harðskeyttari. Pannig kemur skýrt fram í námsáætlun fyrir skóla Kommúnistaflokksins sem samin var í Moskvu að byltingunni fylgdi óhjákvæmilega valdbeiting. ${ }^{60}$ Í ávarpi sem Haavard Langseth, norskur Kominternfulltrúi hafði með sér pegar hann kom til Íslands vorið 1930, er afstaðan til ofbeldislausrar byltingar flóknari. Langseth virðist hafa ætlað sér að ráđast á Einar Olgeirsson fyrir að hafa látið pessa skoðun í ljós, en eftir yfirlestur og ritstjórn ávarpsins í Moskvu er hann beðinn um að láta ógert að minnast á pessa skoðun Einars. ${ }^{61}$

Vel skipulagður aktívistaflokkur eins og Kommúnistaflokkurinn var, einstaklingar sem höfðu dvalið í leynilegum skólum kommúnista í Moskvu og áætlanir yfirlýstra andstæðinga hins borgaralega pjóðskipulags eru ógn í samfélagi eins og pví íslenska, sem á fjórða áratugnum var á viðkvæmu próunarskeiði. Eins og mál próuðust í Evrópu á sama tíma má vissulega ímynda sér að allt hefði getað gerst. Sagnfræðingur parf hinsvegar að fjarlægja sig hita augnabliksins og fjalla um ástandið í ljósi peirra heimilda sem fram koma og varpa ljósi á pað. Áætlunum KFÍ og síðar Sósíalistaflokksins parf að skipta í tvennt. Annarsvegar litu pessir flokkar svo á að bylting pjóðskipulagsins væri óhjákvæmileg í fyllingu tímans og túlkuðu alla atburði með tilliti til pessarar trúar sinnar, sem í sínu innsta eðli var líkari trúarsannfæringu en pólitískri skoðun. Hinsvegar voru peir pátttakendur í stjórnmálabaráttu samtímans og markmið stjórnmálabaráttunnar hverju sinni tóku mið af hversdagslegri verkefnum, par sem munurinn á einstökum stjórnmálaflokkum er oft lítill prátt fyrir ólík lokamarkmið. Ofbeldi var líklegra til að vinna gegn markmiðum kommúnista. Pessvegna voru peir líka fyrst og fremst uppteknir af pví að afla flokki sínum fylgis, styrkja áhrif hans í verkalýðshreyfingunni og á vettvangi stjórnmálanna og pað er dálítið annað en að undirbúa vopnaða (eða óvopnaða) byltingu. Pegar peir purftu að standa fyrir máli sínu gagnvart Komintern í Moskvu á fjórða áratugnum og svara gagnrýnum spurningum sovéskra sendimanna og flokksstarfsmanna síðar, snerust umræðurnar um hugmyndafræði, hreintrúarstefnu og pjálfun ungra flokksmanna annarsvegar, árangur við að laða að kjósendur og nýja flokksmenn hinsvegar. ${ }^{62}$

pað má benda á að örlög kommúnistahreyfingarinnar á Íslandi voru önnur en í Danmörku, Noregi og Svípjóð og mörgum öðrum Evrópulöndum. Í stað pess að einangrast á jaðri stjórnmálanna og glata áhrifum sínum, tókst íslenskum kommúnistum að halda stöðu sinni í miðju stjórnmálanna með pátttöku í blönduðum hreyfingum vinstrimanna. Sósíalistaflokkurinn var fyrsta blöndunin af pessu tagi, pegar vinstriarmur Alpýðuflokksins sameinaðist kommúnistum, og hún hélt áfram á sjötta áratugnum með stofnun Alpýðubandalagsins sem kosningabandalags og síðar pegar pað varð stjórnmálaflokkur. Pótt enginn vilji í dag kalla sig

60 Entwürfe von Lehrplänen für das Parteischulungsnetz der KP Islands, 21.9. 1932. RGASPI 49531 116, bls. 4651.

61 Sjá ónefndur sendandi til Haavards Langseth 1. júní 1930. RGASPI 495 177 3, bls. 17. Skemmtilegt dæmi um barnslega trú á byltingu án ofbeldis, par sem pjóðareining og kommúnismi sameinast, er að finna í grein Kristins E. Andréssonar sem hann skrifaði í tilefni af væntanlegri lýðsveldisstofnun, sjá Kristinn E. Andrésson, „Nýr áfangi, “ bls. 155.

62 Sjá nánar um petta Jón Ólafsson, „Decomposing capitalism: Socialists in power, Iceland 1956-1958,“ bls. 1830. 
arftaka KFÍ, má vel halda pví fram að Vinstri græn varðveiti pá tegund róttækni sem KFÍ stóð fyrir. Sé leitað skýringa á pví hversvegna próun kommúnistahreyfingarinnar var með pessum hætti hér á Íslandi blasir ein skýring við. Hún er sú að forystumenn kommúnista á Îslandi héldu pví sjálfstæði gagnvart Moskvuvaldinu sem skorti víða annarsstaðar. Eins og ég sýni fram á í bók minni Koru félagar nutu forystumenn Sósíalistaflokksins, og pá fyrst og fremst Einar Olgeirsson trúnaðar í Moskvu fram á sjöunda áratuginn jafnvel pótt Sósíalistaflokkurinn væri ekki kommúnistaflokkur í hinum prönga hugmyndafræðilega skilningi sovétkommúnismans. Markmið peirra var pá að tengja Ísland órjúfanlegum böndum við Sovétríkin með viðskiptasamningum. Đað tókst ekki, sem betur fer, pótt Íslendingar nytu góðs af hagstæðum sovétviðskiptum allt til endaloka Sovétríkjanna.

\section{Lokaord}

Nú gæti maður að lokum sagt sem svo að öll fræðileg umræða sé gagnleg. Harðvítugar ásakanir á báða bóga geri hana áhugaverða frekar en hitt. En pótt vissulega geti petta átt við um ýmsa fræðilega umræðu og átök, get ég ekki varist peirri tilhugsun að svo sé ekki um pessa deilu mína við Pór Whitehead og fylgisveina hans. Gallinn við nálgun Pórs er að mínu mati sá að hann einblínir á aukaatriði og beinir par með athygli lesenda frá pví sem raunverulega skiptir máli. Staðhæfingar hans um herbjálfun í Moskvu og gildi hennar fyrir baráttu vinstrimanna á Íslandi, eða sú hugmynd hans að kommúnistar og sósíalistar á Íslandi hafi verið pjónar erlends ríkis er lítt áhugaverð. Fræðileg vinna er nefnilega ómark nema fræðimaðurinn sé tilbúinn til að láta niðurstöður sínar mótast af peim gögnum og heimildum sem fyrir hendi eru á hverjum tíma. Рað er vandalaust fyrir pá sem láta stjórnast af fræðilegum viðhorfum að endurskoða niðurstöður sínar í ljósi nýrra gagna, út á pað ganga fræði. En höfundur sem pykist hafa komist að markverðum niðurstöðum án pess að vinna fyrst nauðsynlega heimildavinnu afvegaleiðir lesendur sína.

Íslenska kommúnistahreyfingin er merkilegt rannsóknarefni, burtséð frá samsæriskenningu Pórs Whitehead sem ýmist dregur í efa eða gerir lítið úr flestum áhugaverðum sérkennum hennar. Hún var sjálfstæðari gagnvart Moskvuvaldinu en margar sambærilegar hreyfingar annarsstaðar, eins og glögglega má sjá af heimildum um hana. Forystumönnum íslenskra sósíalista, einkum Einari Olgeirssyni, tókst að rækta trúnaðarsamband við sovéska framámenn sem Íslendingar, par á meðal íslensk stjórnvöld, hikuðu ekki við að notfæra sér á tímum Kalda stríðsins. Sama gilti um einstaklinga sem voru nátengdir flokknum og hreyfingunni á borð við Kristin E. Andrésson og Halldór Laxness. Pað er ekki nema eðlilegt að pessi tengsl séu umdeild og jafnvel talin forkastanleg. En peir sem harðast ganga fram, par á meðal Pór Whitehead, ættu að gera ítrustu kröfur til sjálfra sín, og að minnsta kosti sömu kröfur og peir gera til annarra, um heimildavinnu og heimildarýni, pví umfjöllun peirra missir annars marks. 


\section{Um höfundinn}

Jón Ólafsson er prófessor við Háskólann á Bifröst. Netfang: jonolafs@bifrost.is. Svanhildur Óskarsdóttir og Guðni Elísson fá sérstakar pakkir fyrir yfirlestur greinarinnar á fyrri stigum og gagnlegar ábendingar.

\section{Heimildaskrá}

\section{Skjalasöfn}

Lbs: Landsbókasafn, handritadeild.

RGASPI: Российский государственный архив социально-политической истории. Vefsíða safnsins (á rússnesku) er http://www.rusarchives.ru/federal/rgaspi.

DÍ: Pjóðskjalasafn Îslands.

\section{Ütgefin rit og greinar}

Arnór Hannibalsson. Moskvulínan. Reykjavík: Nýja bókafélagið, 1999.

Björn Bjarnason. „Jón og fimmta herdeildin.“ Morgunblaðið 6.1. 2007, bls. 32-33.

Cohen, Gidon, og Kevin Morgan. „Stalin's sausage machine: British students at the International Lenin School, 1926-37.“ Twentieth Century British History 13 (4), 2002, bls. 327-355.

Einar Olgeirsson. „Straumhvörf.“ Réttur 15 (3), 1930, bls. 219-236.

Jón Ólafsson, „Staðreyndir eða heilaspuni.“ Mannlif, ágúst 1992, bls. 36-45.

Jón Ólafsson. „Í læri hjá Komintern.“ Ný saga 9, 1997, bls. 4-15.

Jón Ólafsson. Koru félagar: Íslenskir sósíalistar og Sovétríkin 1920-1960. Reykjavík: Mál og menning, 1999.

Jón Ólafsson. „Voru íslenskir kommúnistar hættulegir?“ Lesbók Morgunblaðsins 7.10. 2006, bls. 3.

Jón Ólafsson. „Kommúnistar og stjórnskipulagið: Enn um meinta hættu af íslenskum kommúnistum.“ Lesbók Morgunblaðsins 18.11. 2006, bls. 6-7.

Jón Ólafsson. „Raunveruleiki hins ímyndaða." Ritdómur um bókina Óvinir ríkisins eftir Guðna Th. Jóhannessonar. Lesbók Morgunblaðsins 23.12. 2006, bls. 12.

Jón Ólafsson. „Ímyndaðar herdeildir dómsmálaráðherrans.“ Morgunblaðið 17.1. 2007, bls. 22-23.

Jón Ólafsson. „Decomposing capitalism: Socialists in power, Iceland 1956-1958.“ Tímarit um félagsvísindi 1, 2007, bls. 18-30.

Jón Ólafsson. „Heilagt stríð.“ Lesbók Morgunblaðsins 3.3. 2007, bls. 12-13.

Jón Ólafsson. „Komintern gegn klofningi: Viðbrögð Alpjóðasambands kommúnista við stofnun Sósíalistaflokksins.“ Saga 45 (1), 2007, bls. 93-111.

Jón Ólafsson. „Raunveruleiki fortíðar og eitt minnisblað.“ Saga 47 (1), 2009, bls. 149-161.

Jón Ólafsson. „Nokkur orð um ályktanir og túlkun heimilda.“ Saga 48 (1), 2010, bls. 165-172.

Klehr, Harvey, John Earl Haynes, og F.I. Firsov. The secret world of American communism. New Haven: Yale University Press, 1995.

Krekola, Joni. „The Finnish sector at the International Lenin School.“ Kevin Morgan, Gidon Cohen og Andrew Flinn (ritstj.), Agents of the revolution: new biographical approaches to the history of international communism in the age of Lenin and Stalin. Oxford: Peter Lang, 2005, bls. 289-308.

Kristinn E. Andrésson. „Nýr áfangi.“ Tímarit Máls og menningar, 6 (2), 1944, bls. 154-156. 
Köstenberger, Julia. „Die Geschichte der ,Kommunistischen Universität der nationalen Minderheiten des Westens' (KUNMZ) in Moskau 1921-1936." Jahrbuch für historische Kommunismusforschung VI-VII, 2000/2001, bls. 248-303.

Köstenberger, Julia. „Die Internationale Leninschule.“ Michael Buckmiller og Klaus Meschkat (ritstj.), Biographisches Handbuch zur Geschichte der Kommunistischen Internationale. Berlin: Akademie Verlag, 2005, bls. 297-299.

Murphy, J.T. „Das Erste Jahr der Lenin-Schule und ihre Perspektiven.“ Die Kommunistische Internationale 37, 13.9. 1927, bls. 267-279.

Rønning, Ole-Martin. „Stalins elever.“ Óbirt doktorsritgerð, Háskólinn í Oslo, 2010.

Skafti Ingimarsson. „Fimmta herdeildin.“ Saga 49 (2), 2011, bls. 152-195.

Studer, Brigitte og Berthold Unfried. Der stalinistische Parteikader: Identitätsstiftende Praktiken und Diskurse in der Sowjetunion der dreißiger Jahre. Köln: Böhlau Verlag, 2001.

Styrmir Gunnarsson. „Sovét-Ísland óskalandið eftir Pór Whitehead.“ Djóðmál 7 (1), 2011, bls. 83-85.

Wicks, Harry. Keeping my head: the memoirs of a British Bolshevik. London: Socialist Platform Ltd., 1992.

Pór Whitehead. „Smáríki og heimsbyltingin.“ Pjóðmál 2 (3), 2006, bls. 55-85.

pór Whitehead. „, ,Voru íslenskir kommúnistar hættulegir?‘ Pór Whitehead svarar Jóni Ólafssyni.“ Lesbók Morgunblaðsins 11.11. 2006, bls. 8-9.

pór Whitehead. „Af ávöxtunum skulið pér pekkja pá: Svar til Jóns Ólafssonar.“ Lesbók Morgunblaðsins 20.1. 2007, bls. 6-7.

pór Whitehead. „Eftir skilyrðum Kominterns: Stofnun Sameiningarflokks alpýðu - Sósíalistaflokksins 1937-1938." Saga 46 (2), 2008, bls. 17-55.

pór Whitehead „Eitt minnisblað og óraunveruleiki fortíðar: Svar til Jóns Ólafssonar.“ Saga 47 (2), 2009, bls. 175-184.

Pór Whitehead. Sovét-Ísland óskalandið: Aðdragandi byltingar sem aldrei varð, 1921-1946. Reykjavík: Ugla, 2010. 